\title{
Radiation-induced lung toxicity - cellular and molecular mechanisms of pathogenesis, management, and literature review
}

\author{
Lukas Käsmann ${ }^{1,2,3^{*}}$ D, Alexander Dietrich ${ }^{4}$, Claudia A. Staab-Weijnitz ${ }^{2,5}$, Farkhad Manapov ${ }^{1,2,3}$, Jürgen Behr ${ }^{2,6}$, \\ Andreas Rimner ${ }^{7}$, Branislav Jeremic ${ }^{8}$, Suresh Senan ${ }^{9}$, Dirk De Ruysscher ${ }^{10}$, Kirsten Lauber $^{1,3+}$ and Claus Belka ${ }^{1,2,3 \dagger}$
}

\begin{abstract}
Lung, breast, and esophageal cancer represent three common malignancies with high incidence and mortality worldwide. The management of these tumors critically relies on radiotherapy as a major part of multi-modality care, and treatment-related toxicities, such as radiation-induced pneumonitis and/or lung fibrosis, are important dose limiting factors with direct impact on patient outcomes and quality of life. In this review, we summarize the current understanding of radiation-induced pneumonitis and pulmonary fibrosis, present predictive factors as well as recent diagnostic and therapeutic advances. Novel candidates for molecularly targeted approaches to prevent and/or treat radiation-induced pneumonitis and pulmonary fibrosis are discussed.
\end{abstract}

\section{Introduction}

Lung, breast, and esophageal cancer are common thoracic malignancies with high cancer-associated mortality [1]. In the majority of cases thoracic radiotherapy represents a central part of multi-modal treatment concepts [2]. Several diagnostic and therapeutic advances, such as PETimaging [3, 4], improved radiation delivery techniques [59], implementation of immunotherapy [10-16], and molecularly targeted therapy [17-19], have led to improved outcome in terms of overall survival, local and distant control as well as quality of life. However, between 10 and $30 \%$ of all patients with lung or breast cancer receiving thoracic radiotherapy develop radiation-induced pneumonitis (RIP) as a subacute treatment-associated toxicity,

\footnotetext{
*Correspondence: Ikaesmann@gmail.com

${ }^{\dagger}$ Kirsten Lauber and Claus Belka share equal senior authorship.

'Department of Radiation Oncology, University Hospital, LMU Munich, Marchioninistrasse 15, 81377 Munich, Germany

${ }^{2}$ German Center for Lung Research (DZL), partner site Munich, Munich, Germany

Full list of author information is available at the end of the article
}

and they are at high risk of developing radiation-induced lung fibrosis (RILF) as late toxicity, although treatmentrelated death is uncommon [5, 20-24].

Accordingly, lung toxicity remains a crucial dose limiting factor, and dose escalation trials with conventionally fractionated radiotherapy have been limited by severe lung toxicity [25-27]. Due to the development of novel radiotherapy techniques, including intensity modulated radiotherapy (IMRT) $[5,6]$ and volumetric modulated arc therapy (VMAT) [20], and radiation qualities, such as and proton therapy [28], radiation exposure of normal lung tissue can be significantly reduced. Consequently, the occurrence of RIP grade $\geq 2$ in the treatment of lung cancer has gradually decreased from 30 to $47 \%$ using $2 \mathrm{D}$-radiotherapy [29], to 30-35\% with 3D-radiotherapy [30, 31], 29-32\% with IMRT [31, 32], 24-29\% with VMAT [32, 33], and < $5 \%$ with proton therapy $[28,34]$. The radiation delivery technique is also of importance for the development of RIP and RILF. Different fractionation regimens, such as classically fractionated radiotherapy with 2 Gy per fraction for the 
treatment of rather large tumor volumes, and high precision radiation delivery techniques for the treatment of smaller volumes, such as stereotactic body radiotherapy (SBRT) or stereotactic ablative radiotherapy (SABR), are associated with different risk profiles of RIP/RILF arising from differences in the delivered doses and target volumes. In addition, single- versus multi-fraction course SBRT/ SABR regimens and the localization of the tumor (central versus peripheral) impact radiation-induced lung toxicity [35-37]. Central tumors treated with SBRT often receive more conservative dose fractionation regimens (e.g. SBRT with 3-8 fractions) compared to peripheral tumors resulting in less treatment-related toxicity but comparable outcome [37-39]. High dose single-fraction lung SBRT (e.g. $\geq$ 30 Gy) may be associated with increased toxicity [40, 41]. However, several studies reported low rates of $\geq$ grade III side effects in selected patient cohorts [35, 42].

This review summarizes the current understanding of the cellular and molecular mechanisms underlying the pathogenesis of RIP and RILF. We present predictive factors and the current standards of diagnostic and therapeutic management. Finally, we discuss novel candidates for molecularly targeted approaches to prevent and/or treat RIP and RILF.

\section{Diagnosis of RIP and RILF}

The diagnosis of RIP and RILF is based on clinical presentation and may be supported by associated imaging findings. Various grading scales are used (see Tables 1 and 2). In clinical practice, Radiation Therapy Oncology Group (RTOG) criteria and the Common Terminology Criteria for Adverse Events (CTCAE) are the ones most widely used [43, 44]. However, the majority of all patients will not show any clinical symptoms. Upon conventional thoracic radiotherapy, RIP occurs 1 and 6 months after treatment, typically within 3 months following completion of irradiation. Clinical symptoms include persistent, dry and non-productive coughing, dyspnea (on physical exertion or at rest), low-grade fever, pleuritic pain, and chest discomfort [45]. To date, no standard laboratory test can unequivocally identify RIP. Most patients exhibit normal levels of C-reactive protein (CRP) and diagnostic differentiation from bacterial pneumonia remains challenging [46]. Nevertheless the performance of bronchial lavage sampling with subsequent cytology and immunomonitoring analyses for differential diagnosis of RIP from infectious lung disease is currently under investigation [47].

The benefit of lung function tests for determining the grade of RIP, such as spirometry with lung diffusion capacity test, remains unclear. Several studies investigated changes in lung function after thoracic radiotherapy, and the extent of change in diffusing capacity of lung for carbon monoxide (DLCO) upon radiotherapy of non-small cell lung cancer (NSCLC) patients was reported to be associated with the RIP grade [48, 49]. However, no national or international consensus has yet been established.

Imaging of RIP upon conventional radiotherapy may present with non-specific chest X-ray changes which typically are confined to the irradiated field, with airspace opacities being most common [50]. Pleural effusions or atelectasis may be associated as well. The preferred imaging modality to detect RIP is chest computed tomography $(\mathrm{CT})$, preferably high-resolution computed tomography (HRCT). Chest CTs provide more detailed information about parenchymal changes and often reveal alterations that are localized to the irradiated field, rendering the diagnosis of RIP for clinicians rather obvious [51]. The radiological characteristics of RIP change over time. In the initial phase they include ground-glass opacities and/or airspace consolidation [52]. In some cases, a small ipsilateral pleural effusion may occur in the first 6 months after thoracic irradiation and may persist for several months. In the later phase of RIP after conventional radiotherapy, septal wall thickening may occur with the alveolar opacities producing a "crazy paving" pattern [53]. Upon SABR, radiographic changes will occur in most of the patients within 6 months and can be described as diffuse consolidation ( $>20 \%$ ), patchy consolidation $(>20 \%)$, and

Table 1 Overview about grading scales for radiation-induced pneumonitis

\begin{tabular}{|c|c|c|c|c|c|}
\hline $\begin{array}{l}\text { Grading } \\
\text { scale }\end{array}$ & Grade 1 & Grade 2 & Grade 3 & Grade 4 & $\begin{array}{l}\text { Grade } \\
5\end{array}$ \\
\hline $\begin{array}{l}\text { CTCAE } \\
\vee 5.0\end{array}$ & $\begin{array}{l}\text { Asymptomatic; clinical or } \\
\text { diagnostic observations only; } \\
\text { intervention not indicated }\end{array}$ & $\begin{array}{l}\text { Symptomatic; medical intervention } \\
\text { indicated; limiting instrumental ADL }\end{array}$ & $\begin{array}{l}\text { Severe symptoms; } \\
\text { limiting self care ADL; } \\
\text { oxygen indicated }\end{array}$ & $\begin{array}{l}\text { Life-threatening respiratory } \\
\text { compromise; urgent intervention } \\
\text { indicated (e.g., tracheotomy or } \\
\text { intubation) }\end{array}$ & Death \\
\hline RTOG & $\begin{array}{l}\text { Asymptomatic or mild } \\
\text { symptoms (dry cough); } \\
\text { slight radiographic } \\
\text { appearances }\end{array}$ & $\begin{array}{l}\text { Moderate symptomatic pneumonitis } \\
\text { (severe cough); low grade fever; } \\
\text { patchy radiographic appearances }\end{array}$ & $\begin{array}{l}\text { Severe symptomatic } \\
\text { pneumonitis; dense } \\
\text { radiographic changes }\end{array}$ & $\begin{array}{l}\text { Severe respiratory insufficiency/ } \\
\text { Continuous } 02 \text { / Assisted ventilation }\end{array}$ & Death \\
\hline $\begin{array}{l}\text { LENT- } \\
\text { SOMA } \\
\text { (EORTC) }\end{array}$ & $\begin{array}{l}\text { Asymptomatic or mild } \\
\text { symptoms; slight imaging } \\
\text { changes }\end{array}$ & $\begin{array}{l}\text { Moderate symptoms; moderate } \\
\text { imaging changes }\end{array}$ & $\begin{array}{l}\text { Severe symptoms; } \\
\text { increased density } \\
\text { imaging changes }\end{array}$ & $\begin{array}{l}\text { Severe symptoms requiring } \\
\text { continuous } \mathrm{O} 2 \text { or assisted } \\
\text { ventilation }\end{array}$ & Death \\
\hline
\end{tabular}

CTCAE v5.0 Common terminology criteria for adverse events, version 5.0, RTOG Radiation Therapy Oncology Group, EORTC European Organization for Research and Treatment of Cancer, LENT-SOMA Late effects in normal tissue-subjective objective management analysis 
Table 2 Overview about grading scales for radiation-induced lung fibrosis

\begin{tabular}{|c|c|c|c|c|c|}
\hline $\begin{array}{l}\text { Grading } \\
\text { scale }\end{array}$ & Grade 1 & Grade 2 & Grade 3 & Grade 4 & $\begin{array}{l}\text { Grade } \\
5\end{array}$ \\
\hline $\begin{array}{l}\text { CTCAE } \\
\text { v } 5.0\end{array}$ & $\begin{array}{l}\text { Radiologic pulmonary } \\
\text { fibrosis }<25 \% \text { of lung } \\
\text { volume associated } \\
\text { with hypoxia }\end{array}$ & $\begin{array}{l}\text { Evidence of pulmonary } \\
\text { hypertension; radiographic } \\
\text { pulmonary fibrosis } 25-50 \% \\
\text { associated with hypoxia }\end{array}$ & $\begin{array}{l}\text { Severe hypoxia; evidence of } \\
\text { right-sided heart failure; } \\
\text { radiographic pulmonary fi- } \\
\text { brosis }>50-75 \%\end{array}$ & $\begin{array}{l}\text { Life-threatening consequences (e.g., } \\
\text { hemodynamic/pulmonary complications); } \\
\text { intubation with ventilatory support } \\
\text { indicated; radiographic pulmonary fibrosis } \\
>75 \% \text { with severe honeycombing }\end{array}$ & Death \\
\hline RTOG & $\begin{array}{l}\text { Asymptomatic or mild } \\
\text { symptoms (dry } \\
\text { cough); slight } \\
\text { radiographic } \\
\text { appearances }\end{array}$ & $\begin{array}{l}\text { Moderate symptomatic } \\
\text { fibrosis (severe cough); low } \\
\text { grade fever; patchy } \\
\text { radiographic appearances }\end{array}$ & $\begin{array}{l}\text { Severe symptomatic } \\
\text { fibrosis; dense radiographic } \\
\text { changes }\end{array}$ & $\begin{array}{l}\text { Severe respiratory insufficiency/ Continuous } \\
\text { O2/ Assisted ventilation }\end{array}$ & Death \\
\hline $\begin{array}{l}\text { LENT- } \\
\text { SOMA } \\
\text { (EORTC) }\end{array}$ & $\begin{array}{l}\text { Asymptomatic or mild } \\
\text { symptoms; radiological } \\
\text { abnormalities; } \\
\text { 10-25\% reduction of } \\
\text { respiration volume } \\
\text { and/or diffusion } \\
\text { capacity }\end{array}$ & $\begin{array}{l}\text { Moderate symptoms; patchy } \\
\text { dense abnormalities in } \\
\text { imaging; } \\
>25-50 \% \text { reduction of } \\
\text { respiration volume and/or } \\
\text { diffusion capacity }\end{array}$ & $\begin{array}{l}\text { Severe symptoms; dense } \\
\text { confluent radiographic } \\
\text { changes limited to } \\
\text { irradation field; } \\
>50-75 \% \text { reduction of } \\
\text { respiration volume and/or } \\
\text { diffusion capacity }\end{array}$ & $\begin{array}{l}\text { Severe symptoms requiring continuous } \mathrm{O} 2 \\
\text { or assisted ventilation; } \\
\text { dense fibrosis, severe scarring \& major } \\
\text { retraction of normal lung; } \\
>75 \% \text { reduction of respiration volume } \\
\text { and/or diffusion capacity }\end{array}$ & Death \\
\hline
\end{tabular}

CTCAE v5.0 Common terminology criteria for adverse events, version 5.0, RTOG Radiation Therapy Oncology Group, EORTC European Organization for Research and Treatment of Cancer, LENT-SOMA Late effects in normal tissue-subjective objective management analysis

diffuse or patchy ground glass opacities (>5\%) (see Table 3) $[54,55]$. In contrast to conventional radiotherapy, these changes do usually not occur before 2-3 months after completion of treatment - presumably due to the relevantly shorter treatment course. [18F]fluoro-2-deoxy2-D-glucose positron emission tomography combined with computed tomography (18F-FDG PET/CT) does not contribute to confirming a RIP diagnosis [56]. Inflammatory processes usually demonstrate an increased metabolic activity and are common after thoracic radiotherapy, causing significant confusion when PET/CT is used in the first 6 months after irradiation. However, only the minority of these patients develop clinical RIP.

RILF is typically observed between 6 and 12 months after thoracic radiotherapy and can continuously progress for several years. Several grading scales have been established to categorize RILF (see Table 2). Nearly all patients show (radiographic) signs of RILF following thoracic irradiation [50]. However, the majority of patients with RILF remain asymptomatic, and clinical manifestations are mostly linked to established comorbidities, such as pre-existing lung or heart disorders. Symptoms include dyspnea (upon physical exertion or at rest), persistent and dry coughing, fatigue, and weight loss [45]. Radiographic pulmonary changes are usually observed in the irradiated field but can occur in the rest of the lung as well [57].

Chest X-ray imaging can show volume loss and architectural distortion [56]. In some cases, a mediastinal shift and traction bronchiectasis can be found. Compared to previous chest X-ray scans, progression from RIP increasingly becoming more reticular or linear is typical for RILF. Again, HRCT imaging can better delineate

Table 3 Overview of radiographic changes after completion of conventionally fractionated radiotherapy compared to stereotactic ablative radiotherapy (SABR) of the thorax

\begin{tabular}{|c|c|c|}
\hline & Conventionally fractionated radiotherapy & Stereotactic ablative radiotherapy (SABR) \\
\hline $\begin{array}{l}\text { Radiographic changes within } 6 \text { months after } \\
\text { completion of radiotherapy }\end{array}$ & $\begin{array}{l}\text {-consolidation conform to irradiation field } \\
\text {-diffuse ground glass opacities and/or } \\
\text { airspace consolidation } \\
\text {-nodule-like pattern } \\
\text {-atelectasis } \\
\text {-(ipsilateral) pleural effusion }\end{array}$ & $\begin{array}{l}\text { - diffuse and/or patchy consolidation } \\
\text { - diffuse and/or patchy ground glass opacities }\end{array}$ \\
\hline $\begin{array}{l}\text { Radiographic changes after } 6 \text { months following } \\
\text { completion of radiotherapy }\end{array}$ & $\begin{array}{l}\text {-scar-like fibrosis > conventional pattern > } \\
\text { mass-like fibrosis } \\
\text { •volume loss } \\
\text { •linear scarring/restriction to radiation } \\
\text { fields } \\
\text { •chronic consolidation } \pm \text { air-bronchograms } \\
\text { •bronchiectasis } \\
\text { - pleural thickening } \\
\text {-hilar vascular displacement } \\
\text { •mediastinal shift } \\
\text {-(ipsilateral) pleural effusion }\end{array}$ & $\begin{array}{l}\text { - modified conventional pattern }>\text { scar-like fibro- } \\
\text { sis }>\text { mass-like fibrosis } \\
\text { •chronic consolidation } \\
\text { •volume loss } \\
\text { •bronchiectasis }\end{array}$ \\
\hline
\end{tabular}


parenchymal changes as compared to chest X-ray imaging, including volume loss, linear scarring, and traction bronchiectasis [58]. Chronic consolidation is often found together with air-bronchograms usually exhibiting a non-anatomical distribution. Upon SABR the most frequent late radiographic changes are characterized by consolidation, volume loss, and bronchiectasis in a so called "modified conventional pattern". Previously, straight lines or edges were typically reported as pulmonary changes following conventional 2D- or 3Dradiotherapy. Yet, with current delivery techniques, such as IMRT, VMAT, or SABR, these changes have become rather uncommon, and/or may be more difficult to appreciate without information on the beam configurations used.

A special and very rare form of lung toxicity upon RT for breast cancer is radiation-induced bronchiolitis obliterans organizing pneumonia (BOOP, $<2 \%$ of cases) which may develop several months after RT, commonly with longer latency time compared to RIP [59]. Clinical presentation and radiographic changes are similar to RIP. In contrast to RIP which largely remains limited to the irradiated fields, BOOP is frequently found also in the non-irradiated lung with diffuse patterns and may show patchy alveolar infiltrations \pm air bronchograms and consolidations [60].

The severity of RILF can be radiologically measured with the help of semi-quantitative grading (1-5 points) using radiographic features (see Table 3). "Scar-like" patterns as characterized by streaky opacities in the tumor region are usually associated with less severe RILF due to the mild loss of volume [56]. Conversely, "mass-like" patterns as depicted by focal consolidation and/or ground glass opacification in the tumor region typically with air bronchograms and/or traction bronchiectasis represent rather severe forms of RILF [56]. Upon SABR, "mass-like" fibrosis has been observed more frequently (in up to $14 \%$ of cases) and challenges the diagnosis of local recurrence [54]. In contrast to the equivocal value of 18F-FDG-PET/CT for RIP diagnosis, it can be helpful in differentiating pulmonary fibrosis of radiation-induced origin from recurrent malignancy [56].

\section{Cellular and molecular mechanisms and pathogenesis of RIP and RILF}

The alveolar tissue of the lung is relatively sensitive to ionizing radiation $[61,62]$. Therefore, RIP and RILF are major dose limiting adverse effects interfering with the radiotherapeutic success in the treatment course of thoracic malignancies [63-66]. The pathogenesis of RIP and RILF is a complex multi-step process involving several resident cells of the lung as well as recruited immune cells and is initiated and perpetuated via pleiotropic inter- and intracellular communication and signaling events [67-69]. According to the current understanding, an overwhelming cascade of damage-associated molecular patterns (DAMPs), pro-inflammatory cytokines, and chemokines released by dying and/or senescent epithelial cells, endothelial cells, and activated immune cells essentially contribute to the development of RIP and RILF (see Figs. 1 and 2) $[66,70]$.

Radiation-induced lung toxicity can be divided into three phases: Acute, subacute, and late radiation toxicity. In the acute phase, occurring minutes to days after irradiation, repair of radiation-induced DNA damage takes place in the lung tissue. This includes base modifications, single and double strand breaks of varying complexity, DNA crosslinks, and bulky lesions which arise from direct ionization events or are indirectly mediated by free reactive oxygen species (ROS), respectively [71]. Acute radiation-induced toxicity appears to primarily involve alveolar type I (AT I) and II (AT II) epithelial cells, and endothelial cells [62]. Whereas most tumor cells preferentially undergo necrotic forms of cell death upon radiation at clinically relevant doses, normal tissue epithelial cells and endothelial cells predominantly show phenotypes of cellular senescence [66, 72]. Intriguingly, radiation-induced senescence is accompanied by an altered gene expression profile and the release of several pro-inflammatory cytokines and chemokines, constituting the senescence-associated secretory phenotype (SASP) [73]. Major representatives of SASP cytokines include transforming growth factor- $\beta$ (TGF- $\beta$ ), plateletderived growth factor (PDGF), interleukins (IL) $-1,-6$, and -8 as well as ligands of the CXCR $1 / 2$ and CCR2/5 chemokine receptors. These mediators enforce cellular senescence in parenchymal cells, stimulate endothelial cell activation, and contribute to the recruitment and activation of immune cells [68]. Moreover, DNA damageinduced senescence and death of AT I and AT II cells result in a loss of barrier function and reduced surfactant production, decreased surface tension, and possible atelectasis due to the lack of surfactant eventually leading to interstitial edema, exudation of proteins into the alveolar space, and further reduction of the alveolar septa [74-77]. The microvascular system of the lung tissue and particularly endothelial cells are also affected by radiotherapy, both directly via DNA damage-induced senescence and indirectly via released DAMPs and SASP cytokines giving rise to increased vascular permeability and decreased vascular integrity further amplifying the damage of AT I and AT II cells (see Fig. 1) [76]. Ultimately, the affected lung tissue will develop sterile alveolitis with further infiltration of immune cells.

The subacute phase, which can last for several months, is defined by the recruitment of several effector cells of the innate and adaptive immune system (neutrophils, monocytes, macrophages, and lymphocytes) and the concomitant release of pro-inflammatory cytokines which 


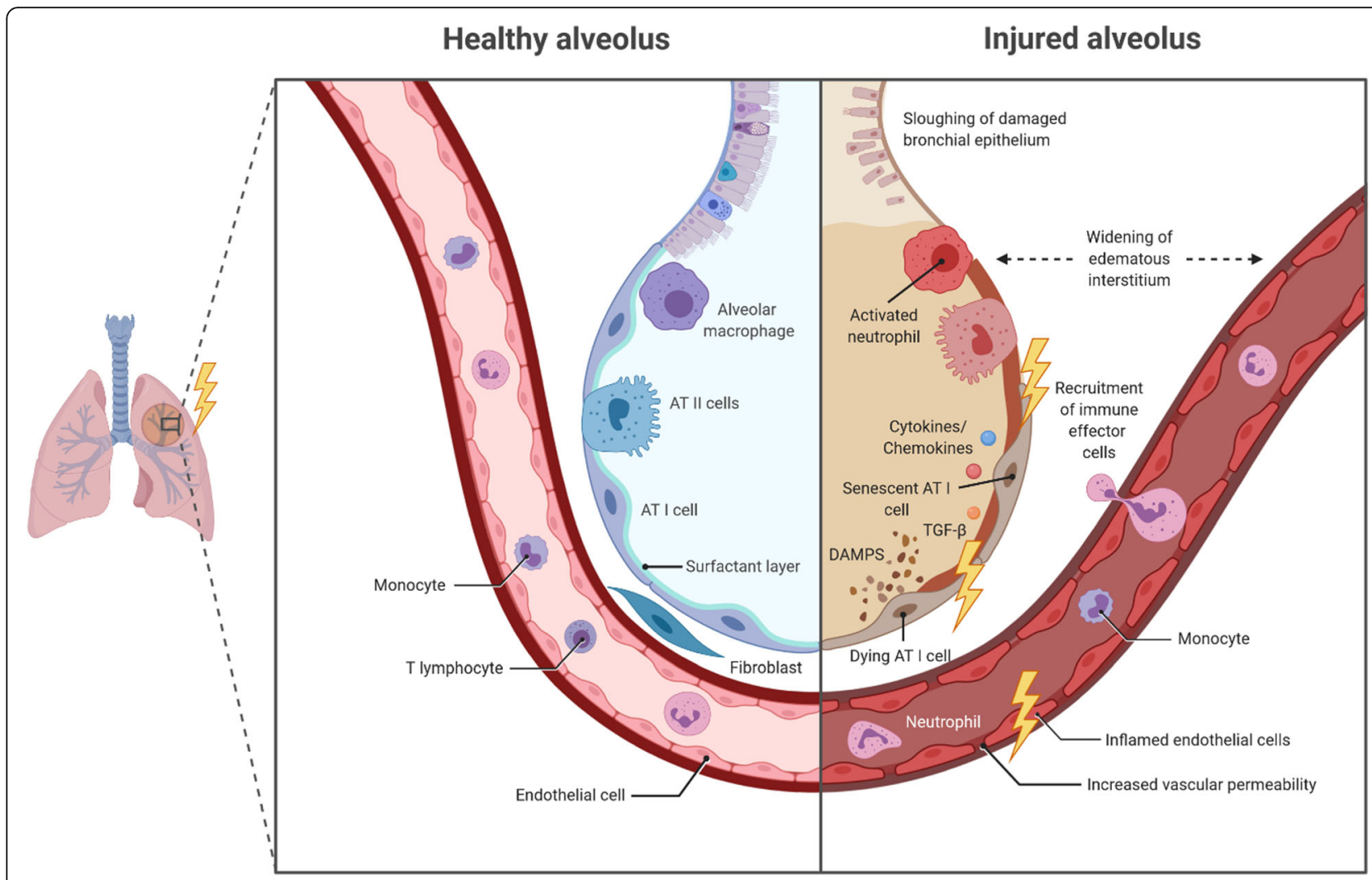

Fig. 1 Overview about radiation-induced acute and subacute alveolar changes. AT I cell: alveolar type I cell; AT II cell: alveolar type II cell; DAMP: damage-associated molecular pattern; TGF- $\beta$ : transforming growth factor $\beta$

trigger extensive tissue remodeling of the lung. Immune cell infiltration into the injured lung is facilitated by increased vascular permeability, augmented expression of adhesion molecules (e.g. intercellular adhesion molecule 1 (ICAM-1) and platelet endothelial cell adhesion molecule 1 (PECAM-1) on activated endothelial cells, and release and deposition of chemokines [78]. The initial recruitment of neutrophils is followed by monocytes, macrophages, and lymphocytes (see Fig. 1) [79, 80], and immune-cell derived cytokines, including tumor necrosis factor (TNF), TGF- $\beta$, IL-2, IL-3, IL-4, IL-6, IL-7, and IL-8, enforce the activation and proliferation of fibroblasts [81-84]. For a more detailed assessment of the contribution of distinct immune cell subsets, the interested reader is referred to Wirsdörfer et al. [85], Kainthola et al. [86] and McKelvey et al. [87].

Apart from the described immune-mediated tissue remodeling events, hypoxia has been reported to contribute to the onset and the perpetuation of RIP and RILF [76]. Radiationinduced hypoxia occurs several days after thoracic radiotherapy and has been reported to increase over time in different animal models [76, 88]. Importantly, hypoxia-induced downstream signaling leads to upregulation of TGF- $\beta$, enhanced collagen synthesis, and changes in the lung architecture (see Fig. 2). In summary, all these events contribute to the development and establishment of RIP which represents the acute, but reversible scenario of radiation-induced lung toxicity. Of note, elevated serum levels of TGF- $\beta$ are associated with increased risk of RIP [89].

The late phase of radiation-induced lung injury can be defined by the irreversible rearrangement of lung architecture which occurs several months following thoracic radiotherapy [58]. Again, TGF- $\beta$ produced by activated immune cells as well as by AT I/II cells and fibroblasts, appears to be a key player due to its profibrotic functions (see Fig. 2) $[89,90]$. TGF- $\beta$ acts by binding to two serine/ threonine kinase receptors, namely TGF- $\beta$ type I and type II receptors, resulting in the activation of multiple signaling cascades, including the small mother against decapentaplegic (SMAD) 2/3, mitogen-activated protein kinase (MAPK) and extracellular signal-regulated kinase (ERK) signaling pathways [77, 91-93]. Activated Smad2/3 forms complexes with Smad4, subsequently translocating to the nucleus and regulating the expression of genes associated with fibroblast proliferation, migration, and collagen synthesis in the lung tissue $[77,91]$. TGF- $\beta$ stimulates the expression of fibrillar collagens (type I, III and type V) and fibronectin by fibroblasts in the interstitial space resulting in stiffening of the alveolar area and reduction of gas exchange [94-96]. Additionally, overexpression of TGF- $\beta$ in 


\section{Radiation-induced lung fibrosis (RILF) Late alveolar changes}

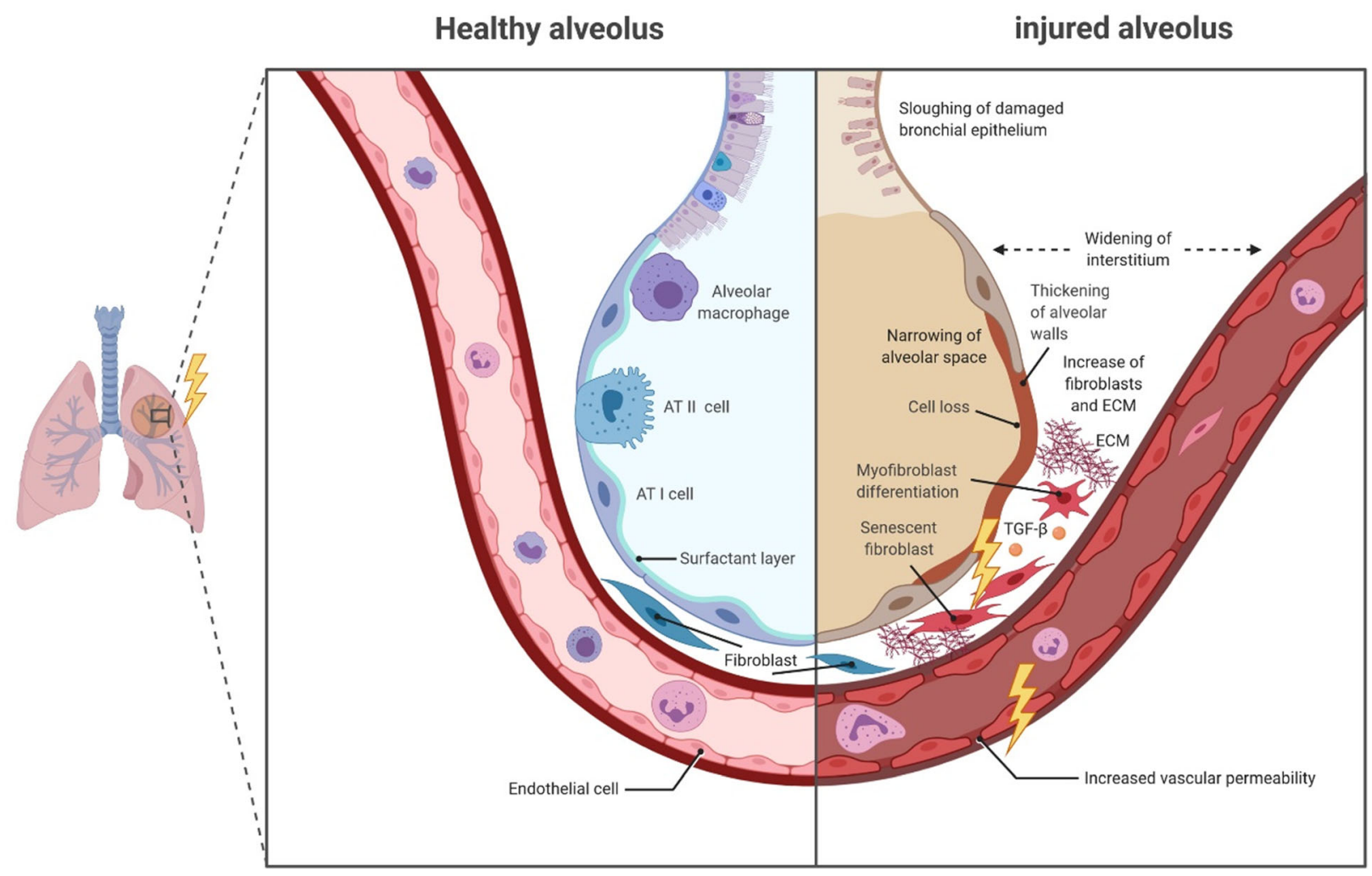

Fig. 2 Overview about radiation-induced late alveolar changes. AT I cell: alveolar type I cell; AT II cell: alveolar type II cell; ECM: extracellular matrix; TGF- $\beta$ : transforming growth factor $\beta$

experimental models of fibrosis was observed to be accompanied by upregulation of protease inhibitors, such as tissue inhibitor of metalloproteinases (TIMP) and plasminogen activator inhibitor-1 (PAI-1), along with an excessive accumulation of matrix proteins and collagens $[97,98]$. TGF- $\beta$ stimulates the differentiation of fibroblasts into myofibroblasts which comes along with induction of $\alpha$-smooth muscle actin ( $\alpha$-SMA) and increased contractility [99]. Thus, lung architecture remodeling culminates in increasing stiffness and thickening of the lung parenchyma due to the overproduction of extracellular matrix proteins, and the alveolar space is severely reduced [100]. These architectural changes in the lung and the expansion of irreversibly fibrotic regions during the late phase after thoracic radiotherapy are apparent in chest CTs as pulmonary fibrosis.

\section{Predictors of RIP}

RIP occurs in the subacute phase after radiotherapy and is mainly characterized by increased infiltration of immune effector cells, such as neutrophils, monocytes, and macrophages, and the release of pro-inflammatory cytokines and chemokines. In order to prevent the development of RIP and RILF in the radiotherapeutic routine, several risk factors have been identified. The predictors of RIP can be patient-, disease-, and/or treatment-related.

\section{Patient-related risk factors of RIP}

Several patient-related characteristics, such as age, sex, performance status, smoking status, and comorbidities, have been suggested as risk factors for RIP. In a metaanalysis of 31 independent studies with patients of different thoracic malignancies (lung, breast, and esophageal cancer), older age (odds ratio $(\mathrm{OR})=1.7, p<0.0001$ ) and pre-existing comorbidities ( $\mathrm{OR}=2.3, p=0.007)$ were identified as potential risk factors for the development of RIP [101]. In contrast, a subsequent study with 576 patients identified no significant differences in the incidence of grade $\geq 3$ RIP between patients $\leq 60$ and $>60$ years $(p=$ 0.943 ) [102], and other studies also failed to find significant associations between increasing age and the occurrence of RIP [102-104]. In summary, age should be considered as a relevant risk factor for RIP, but lung comorbidities and radiotherapy features may be more important risk factors compared to chronological age alone. 
The role of the patients' sex remains controversial. In average, women appear to have smaller tumor volumes and have more often a non-smoking history compared to men [105]. Therefore, their pre-radiotherapy lung capacity (FEV1, DLCO) is usually better than the one of male patients.

Pre-existing lung disease, such as chronic obstructive pulmonary disease (COPD) or interstitial lung disease (ILD), can confound the diagnosis of RIP and occurs quite frequently in lung cancer patients. The predictive role of COPD appears controversial. While patients with extensive emphysema experience RIP in more than 50\%, and several studies suggest an increased risk of RIP in patients with underlying COPD [106, 107], other reports do not confirm these observations [102, 108]. Patients with pre-existing ILD seem to be more susceptible to RIP and are at markedly increased risk of radiationinduced toxicity $[109,110]$. A retrospective analysis of 504 patients undergoing thoracic SABR reported grade $\geq$ 3 RIP in $32 \%$ and grade 5 pneumonitis in $21 \%$ of all ILD patients compared to a general risk of less than $10 \%$ of grade $\geq$ III RIP after SBRT [111-113]. Further studies observed an SABR-related mortality rate of $16 \%$, and it was recommended to reduce the radiation dose for patients with pre-existing ILD in order to prevent radiation-induced lung toxicity [114]. Accordingly, stricter than normal dose constraints may need to be applied in these cases [110, 115], and careful weighing of the risks and benefits for each individual patient is critical in this population at high risk for severe toxicity. Informed consent should include a clear description of the risks. Alternative treatment options, including close observation, should be explored and considered [109]. Interstitial lung abnormalities (ILAs) are defined as precursor stages of idiopathic pulmonary fibrosis and show similar, but less severe radiological changes compared to ILD [116]. Although ILAs mostly remain asymptomatic or subclinical, they are frequently observed in lung cancer screening trials and need particular attention [117]. The ILA classifying radiographic changes include non-fibrotic (ground glass opacification, areas of consolidation, mosaic attenuation) as well as fibrotic features (ground glass opacification with reticulation, honeycombing). Importantly, patients with ILAs show lower exercise tolerance, a restrictive pattern in lung function tests, higher risk of developing clinically significant ILD, and an increased overall mortality [118]. Along these lines, patients with pre-existing ILAs also seem to be more susceptible to radiation-induced toxicity $[109,110]$. Therefore, physicians should perform a comprehensive risk assessment, including clinical (prior symptoms, diagnosis, lung function with DLCO) and imagebased evaluation, and the radiotherapeutic treatment of patients with ILA should be carefully discussed - preferentially in a process of shared decision-making. Ongoing trials, such as ASPIRE-ILD phase II study (NCT034853 78), are currently prospectively investigating the safety and efficacy of SBRT in patients with inoperable early stage NSCLC with pre-existing ILD and ILA [119].

\section{Disease-related risk factors of RIP}

Disease-related factors of RIP include the tumor location and the tumor volume. The location of the tumor was reported to be associated with the risk of RIP in several studies and meta-analyses identifying patients with tumors in the middle or lower lobes to be at higher risk [101, 103, 120]. A significantly elevated risk of RIP was described for patients with tumors in the inferior part of the lung [103]. The increased risk of RIP may reflect differences in radiosensitivity between different regions of the lung. The caudal part of the lung contains more lung volume and shows stronger movements compared to the cranial part - especially in patients with emphysema.

In addition, increasing tumor volumes seem to be associated with higher probabilities to develop RIP [121124]. Accordingly, treatment volume planning, motion management, and delivery verification strategies are critical. Nevertheless, there is currently no consensus in the literature on the reporting of cut-offs as well as on the used radiation delivery techniques. Moreover, tumor volumes can be described by different measures which are inconsistently used, including gross tumor volume (GTV), clinical target volume (CTV), planning target volume $(\mathrm{PTV}) \pm$ involved lymph node volume, and lung volume minus GTV, CTV, or PTV, respectively. Interestingly, the irradiated lung volume was not significantly associated with radiation-induced BOOP after radiotherapy for breast cancer [60].

Apart from the tumor volume and its location, its proximity to the heart and - in consequence - the radiation dose delivered to the heart impacts the risk of RIP and RILF [125-127]. Importantly, the dosimetric values of the heart are not simply surrogate markers for dosimetric lung parameters [127]. The underlying mechanisms have not been understood yet, but dose constraints to the heart need to be critically considered to prevent RIP and RILF.

In contrast, the tumor stage has not been confirmed as a risk factor for RIP [46, 102, 128]. Hence, tumor volume rather than tumor stage should be considered as a relevant risk factor for RIP, but clear cut-off values remain to be defined for both conventional and SABR populations.

\section{Treatment-related risk factors of RIP}

Treatment of thoracic malignancies involves radiotherapy, surgery, and various systemic therapies. As a result, different treatment modalities are accompanied by different risks for the development of RIP. Several studies reported that previous surgery leads to a higher risk of 
RIP [126, 129]. However, in a meta-analysis including 6 studies with 800 patients, surgery was not confirmed as a risk factor for RIP [101]. The extent of resection and differences in postoperative treatments may represent confounding factors and thus should be analyzed in greater detail.

Systemic treatment options include several different agents, combinations, and that affect radiation-induced lung toxicity [130]. Compared to other anticancer drugs, paclitaxel-based chemotherapy has been described to be associated with higher risks of RIP [124, 131-133]. Additionally, a meta-analysis found that sequential rather than concurrent chemotherapy $(\mathrm{OR}=1.6, p=0.01)$ seems to increase the RIP risk. Yet, treatment intensity and patient selection may confound these findings and thus need to be considered [101]. Conflicting results were reported in a different meta-analysis including 1205 patients from seven randomized clinical trials which showed no significant differences between concomitant and sequential chemotherapy for grade $\geq 3$ acute pulmonary toxicity (relative risk (RR): 0.69; $95 \%$ CI: 0.42 to $1.12 ; p=0.13)$ [134].

Parameters extracted from dose-volume histograms may offer the most resilient predictors of radiationinduced toxicity. In the literature, the mean lung dose (MLD) and the lung volume receiving 20 Gy (V20) are the most frequently and robustly reported risk factors $[124,135]$. It is recommended to limit V20 to $\leq 30-35 \%$, and MLD to $\leq 20-23$ Gy in normofractionated radiotherapy to limit the risk of RIP to $\leq 20 \%$ in patients with NSCLC [124]. Hypofractionated radiotherapy with single doses of $\geq 2.5 \mathrm{~Gy}$ is associated with higher rates of RIP $[124,136]$. For SBRT, V20 $>10 \%$ and MLD $>6$ Gy were associated with higher risk of grade 2-4 RIP [137-139]. Apart from these established dose constraints, the concept of the "critical volume" has been increasingly used [140]. According to this concept, a minimum of approximately one-third of the total native lung volume (with connection to the body via a functional hilum) needs to be spared from the threshold dose in order to maintain the basic organ function. Several protocols defining the critical lung volume have been published, ranging from 1000 to $1500 \mathrm{~cm}^{3}$ [140-142]. Future studies are needed to provide additional guidance for physicians and to assess the performance of the critical volume concept with regards to preventing radiation-induced toxicity.

With the clinical implementation of immunotherapeutic protocols, the impact of immune checkpoint inhibition (ICI) on the development of RIP needs to be examined and is currently under investigation [143, 144]. Programmed cell death 1 (PD-1)/ Programmed cell death 1 ligand 1 (PDL1) inhibition alone can cause immune-mediated pneumonitis in less than 5\% [145]. Furthermore, radiation recalls several months after thoracic radiotherapy while ICI is still being administered have been described in some cases $[144,146]$. The first systematic retro- and prospective studies have shown acceptable toxicity of sequential and concurrent radio-immunotherapy [147-150]. However, the risk of RIP and immune-mediated pneumonitis may still be underestimated [144, 151]. Unfortunately, predictive biomarkers and/or patient- or disease-related characteristics that can identify patients with elevated risk of RIP with ICI treatment are currently not available [152], but several ongoing studies are investigating these multi-modal treatment approaches and aim at establishing such biomarkers (NCT03519971 (PACIFIC-2), NCT04245514 (SAKK 16/ 18), NCT03801902 (NRG-LU004), NCT03217071). For the time being, careful monitoring of radiation and/or immune-mediated pneumonitis and appropriate treatment management strategies with the aim of reducing risk and/ or enabling early symptom detection are needed [153].

\section{Prevention of radiation-induced lung injury}

Although distinct improvements in radiation treatment planning and delivery techniques (IMRT, VMAT) allow sparing the healthy tissue while escalating the dose administered to the tumor, RIP and RILF remain dose limiting factors of thoracic radiotherapy which strongly affect the therapeutic outcome and quality of life. In order to improve outcome in patients with locally advanced stages of thoracic cancer, multi-modal treatments combining radio-, chemo- and/or immunotherapy are increasingly being employed and often represent the standard of care [13, 14, 154]. Besides technical advances to reduce radiation-induced toxicity, such as the implementation of IMRT and VMAT, no evidence-based pharmacological intervention has been found so far. Several agents are currently under investigation to prevent and/or treat RIP and RILF, namely protectors, modifiers, and mitigators of radiation-induced lung toxicity. Diverse mechanisms of action have been suggested. As such, radiation protectors would be given before radiotherapy, mitigators would be administered during or immediately after irradiation but before the occurrence of radiation-induced toxicity, and modifiers of radiation-induced lung toxicity would be employed after the appearance of RIP or RILF in order to attenuate progression or to reverse the damage. However, the best strategy seems to be investigating novel radiation delivery techniques (image-guided radiotherapy (IGRT), magnetic resonance (MR)-guided radiotherapy) and radiation qualities (proton, particle therapy) combined with promising pharmacological intervention in order to obtain optimal results.

ACE (angiotensin-converting enzyme) inhibitors and angiotensin-II receptor subtype 1 (AT-1) antagonists have been shown to be helpful in mitigating radiation-induced damage by targeting inflammatory and fibrogenic pathways in preclinical model systems [90, 155, 156]. Angiotensin-II 
stimulates TGF- $\beta$ expression via upregulation of toll-like receptor 4 (TLR4) [157] and $\alpha$-SMA via mechanisms involving serum response factor (SRF) [158]. Accordingly, AT-1 receptor antagonists may counteract these effects. The ACE inhibitor enalaprilat as the active metabolite of enalapril has been reported to attenuate levels of TGF- $\beta$, vascular remodeling, and subsequent lung fibrosis [156]. Similarly, the application of captopril was associated with a reduction in pulmonary complication-associated mortality after total body irradiation in a randomized controlled trial [159]. Despite of the strong preclinical evidence, ACE inhibitors and AT-1 receptor antagonists need to be investigated further in prospective trials.

Amifostine is traditionally used to attenuate accumulating renal toxicity and/or xerostomia during anti-cancer chemo (radio)therapy. Several clinical trials incorporating amifostine reported a particularly low rate of clinically apparent pneumonitis upon thoracic chemoradiotherapy for lung cancer patients [160-165]. However, major methodological limitations, including lacking predefinition of time, type of evaluation, lacking inclusion of established risk factors (radiotherapy doses and volumes), and missing control groups limit the informative value of these studies. In the so far largest clinical trial on amifostine only "late lung toxicity" was evaluated [166], and none of the mentioned studies found a reduced rate of clinically and/or radiologically detectable subacute or late lung toxicity upon administration of amifostine [167]. In contrast to radioprotective effects on normal tissues, tumor-protective effects of amifostine can be largely ruled out $[167,168]$. However, amifostine can cause adverse effects ranging from nausea and hypotension to myocardial infarction and a poor tolerability (especially when administered intravenously), thus limiting its clinical use.

Prophylactic use of inhalative corticosteroids has been suggested to prevent radiation-induced lung toxicity. However, despite encouraging preclinical results, clinical trials failed to show efficacy of inhalative corticosteroids in the prevention of RIP and RILF [169, 170]. Symptomatic RIP grade 2 patients were successfully treated with inhaled steroids, such as beclomethason [170]. Nevertheless, not all patients may respond to inhaled treatment, and treatment intensification could be necessary with close clinical observation. In contrast to the oral application with a high first pass effect, inhaled application of corticosteroids is accompanied by lower risks of systemic side effects, such as weight gain, hyperglycemia, and sleep disturbances, and thus should be investigated in larger trials.

Pentoxifylline is a phosphodiesterase inhibitor which downregulates the production of pro-inflammatory cytokines, particularly TNF. In preclinical studies, administration of pentoxifylline prior to whole thorax irradiation has been reported to reduce TNF mRNA and protein levels [171]. Furthermore, pentoxifylline-mediated phosphodiesterase inhibition results in reduced leukocyte adherence to endothelial cells, less platelet aggregation, and dilatation of capillaries. In a small placebo-controlled phase II study, pentoxifylline reduced the occurrence of high grade pneumonitis and decreased lung function loss after 3 and 6 months [172] confirming earlier results [173, 174]. However, the small number of included patients, heterogeneous treatment and follow-up monitoring as well as the different primary endpoints of the studies need to be considered, and further randomized controlled trials are warranted.

Mechanistically, TGF- $\beta$ is a central player in the development of both RIP and RILF. Thus, inhibition of TGF- $\beta$ and/or its downstream signaling cascades represents an attractive strategy to prevent radiation-induced lung toxicity. Several in vivo studies described reduced inflammation and lung fibrosis upon TGF- $\beta$ receptor inhibition with LY2109761, a TGF- $\beta$ receptor I/II kinase inhibitor which interferes with SMAD1/2 phosphorylation, attenuates TGF- $\beta$ signaling, and suppresses production of the pro-inflammatory cytokines IL-6, IL-7R, and IL-8 [175, 176]. LY2157299 (galunisertib) more specifically inhibits TGF- $\beta$ receptor I and has already convinced in phase II clinical trials for idiopathic pulmonary fibrosis (IPF) with manageable toxicity [177]. Its relevance for the prevention of RILF remains to be evaluated. Pirfenidone is an antifibrotic agent with approval for the treatment of idiopathic pulmonary fibrosis (IPF) that also counteracts TGF- $\beta$ signaling by downregulating pro-fibrotic cytokines, attenuating lung fibroblast proliferation, and decreasing extracellular matrix deposition [178-181]. Several ongoing or unpublished trials currently investigate pirfenidone for its prophylactic performance in radiation-induced lung toxicity (NCT02296281, NCT00020631).

Platelet-derived growth factor (PDGF) is another cytokine involved in the development of RILF via its engagement in downstream signaling of fibrotic cytokines, such as TGF- $\beta$, IL-1, and TNF [176]. Along these lines, the preventive potential of several PDGF receptor inhibitors has been investigated in the context of radiation-induced lung toxicity in vitro and in vivo [182, 183]. Collectively, the findings suggest that the development of lung fibrosis can be inhibited by perturbing fibrotic signaling events and that this strategy is more promising than interfering with inflammation [183]. However, in clinical trials for idiopathic pulmonary fibrosis (IPF), PDGF inhibitors, such as imatinib, failed to prolong survival and/or improve lung function [184] - in contrast to nintedanib which appears safe and slowed down IPF progression considerably [185, 186]. Clinical performance of PDGF inhibitors for the prevention of radiation-induced lung toxicity is currently being trialed (NCT02496585, NCT02452463).

Connective tissue growth factor (CTGF) is a further potential target for the prevention of RILF that was adopted from trials on IPF. It is a matricellular protein 
involved in tissue remodeling, myofibroblast differentiation, adhesion, and angiogenesis. In vivo experiments demonstrated that CTGF inhibition can attenuate the development of radiation-induced lung fibrosis and even to revert the fibrotic processes in a therapeutic setting [187]. Moreover, FG-3019 (pamrevlumab), a neutralizing antibody designed against CTGF, appears to be more potent than pirfenidone or nintedanib (PDGFR/VEGFR/ FGFR inhibitor) in a mouse model of radiation-induced lung fibrosis [188]. Nevertheless, despite successfully completed phase II clinical trials of pamrevlumab in IPF [189], its potential to prevent radiation-induced lung toxicity needs further evaluation.

Apart from cytokines, extracellular adenosine contributes to the development of RILF. It is released by irradiated cells or generated from extracellular adenine nucleotides by the interplay of the ectoenzymes ectoapyrase (CD39) and 5'ectonucleotidase (CD73), respectively [190]. Targeting the CD39/CD73/adenosine axis via administration of PEGylated adenosine deaminase or CD73 antibodies resulted in significantly attenuated RILF in preclinical settings [191] and thus represents a promising pharmacological strategy for future clinical trials.

Several transient receptor potential cation channels (TRPs) are expressed in the lung and have been found to mediate inflammatory and fibrotic processes, such as interstitial edema and lung fibrosis. TRPM2 is involved in acute and late radiation-induced toxicity, and its PARP1-dependent activation upon exposure to ionizing irradiation has been described to contribute to the development of xerostomia in a mouse model [192]. Furthermore, TRPM2-deficient mice exhibit less inflammation and dermatofibrosis in response to radiotherapy as compared to wild type mice [193]. Thus, the role of TRP channels as potential therapeutic target in the prevention of RIP and RILF needs further investigation [194].

Finally, mesenchymal stem cells (MSCs) have been shown to exhibit strong regenerative capacity for several forms of tissue damage [195]. MSCs can successfully migrate towards the injured site in the lung upon irradiation and differentiate into distinct lung cell types, including AT I/II cells and endothelial cells. Preclinical studies reported that lung fibrosis can be modulated by administration of MSCs $[195,196]$. In these settings, adoptive transfer of MSCs did limit radiation-induced endothelial cell loss in the early phase after irradiation and promoted tissue repair through the secretion of superoxide dismutase 1 (SOD1) [197] and the anti-fibrotic factors hepatocyte growth factor (HGF) and prostaglandin E2 (PGE2) [198]. Initial phase I trials on IPF confirmed safety of MSC application and reported promising outcomes [199, 200].

\section{Treatment of RIP and RILF}

National and international guidelines recommend treating RIP only if symptomatic with corticosteroids according to clinical severity based on consensus guidelines due to limited clinical data. The treatment should be carried out over at least several weeks and subsequently should be slowly tapered (see Table 4) [201]. Abrupt discontinuation should be avoided in order to prevent early relapse of RIP (rebound phenomenon) with increased severity and higher risk of RILF development. For asymptomatic or subclinical patients, clinical observation without further treatment is recommended. Patients with radiation-induced BOOP usually show fast and effective responses to steroid treatment [202]. Prophylactic administration of antibiotics in RIP can be considered for patients at high risk of bacterial infection, for instance with cancer-associated bronchial stenosis, or for immunocompromised patients. If symptoms persist under treatment with steroids and/or antibiotics, antifungal treatment may be subscribed. Steroid doses can be reduced in combination with azathioprine or cyclosporine A. For individual cases, these agents can be used if corticosteroid treatment fails. Respiratory gymnastics and inhalation of $\beta$-sympathomimetics have been reported to be supportive. In severe cases of RIP (CTCAE $\geq \mathrm{III}$ ), administering oxygen, assisted ventilation and prophylaxis of right heart failure are needed. A successful treatment option for RILF has yet not been established.

\section{Conclusions}

RIP and RILF remain dose limiting forms of radiationinduced lung toxicity with relevant impact on the success of thoracic radiotherapy. Several patient-, diseaseand treatment-related factors, namely age, pre-existing lung disease, tumor location, radiation dose, and irradiated volume, need to be considered when trying to predict their risk of occurrence. This is of particular importance in complex settings of multi-modal radiochemo-immunotherapy with or without prior surgery. Refined radiation delivery techniques, including motion management and treatment verification strategies, can reduce the irradiated lung volume and should be considered for patients with high risk of RIP. The current repertoire of preventive and/or therapeutic intervention by administration of radiation protectors, modifiers, and/or mitigators remains rather limited. But with growing knowledge of the underlying cellular and molecular mechanisms of radiation-induced lung toxicity, promising targets and pathways have been and will be identified

Table 4 Treatment with corticosteroids in responsive patients with moderate RIP (CTCAE I-II)

\begin{tabular}{ll}
\hline Treatment period (days) & Prednisolone dose (mg/day) \\
\hline $1-4$ & 60 \\
$5-8$ & 30 \\
$9-14$ & 12 \\
$>15$ (ca. 6 weeks) & 6 \\
\hline
\end{tabular}


to serve as future therapeutic options - preferentially in combination with novel radiation delivery techniques.

\begin{abstract}
Abbreviations
2D: 2-dimensional; 3D: 3-dimensional; 18F-FDG PET/CT: [18F]fluoro-2-deoxy2-D-glucose positron emission tomography combined with computed tomography; ACE: Angiotensin-converting enzyme; AT I: Alveolar type I; AT II: Alveolar type II; BOOP: Bronchiolitis obliterans organizing pneumonia; COPD: Chronic obstructive pulmonary disease; CRP: C-reactive protein; CT: Computed tomography; CTCAE: Common terminology criteria for adverse events; CTGF: Connective tissue growth factor; CTV: Clinical target volume; DAMP: Damage-associated molecular pattern; DLCO: Diffusing capacity of lung for carbon monoxide; DNA: Deoxyribonucleic acid; ERK: Extracellular signal-regulated kinase; FEV1: Forced expiratory volume in one second; GTV: Gross tumor volume; HGF: Hepatocyte growth factor; HRCT: High-resolution computed tomography; ICAM-1: Intercellular adhesion molecule 1; ICI: Immune checkpoint inhibition; IGRT: Image-guided radiotherapy; IL: Interleukin; ILA: Interstitial lung abnormality; ILD: Interstitial lung disease; IMRT: Intensity modulated radiotherapy; MAPK: Mitogenactivated protein kinase; MLD: Mean lung dose; MR: Magnetic resonance; MSC: Mesenchymal stem cell; NSCLC: Non-small cell lung cancer; OR: Odds ratio; PAI-1: Plasminogen activator inhibitor-1; PARP1: Poly [ADP-ribose] polymerase 1; PD-1: Programmed cell death 1; PDGF: Platelet-derived growth factor; PD-L1: Programmed cell death 1 ligand 1; PECAM-1: Platelet endothelial cell adhesion molecule 1; PGE2: Prostaglandin E2; PTV: Planning target volume; RILF: Radiation-induced lung fibrosis; RIP: Radiation-induced pneumonitis; ROS: Reactive oxygen species; RTOG: Radiation Therapy Oncology Group; SABR: Stereotactic ablative radiotherapy; SASP: Senescenceassociated secretory phenotype; SBRT: Stereotactic body radiotherapy; SMAD: Small mother against decapentaplegic; SOD1: Superoxide dismutase 1; SRF: Serum response factor; TGF- $\beta$ : Transforming growth factor- $\beta$; TIMP: Tissue inhibitor of metalloproteinases; TLR4: Toll-like receptor 4; TNF: Tumor necrosis factor; TRP: Transient receptor potential cation channel; TRPM2: Transient receptor potential cation channel member 2; V20: Lung volume receiving $20 \mathrm{~Gy}$; VMAT: Volumetric modulated arc therapy; a-SMA: asmooth muscle actin
\end{abstract}

\section{Acknowledgements}

This manuscript has not been previously published and is not under consideration elsewhere. The persons listed as authors have given their approval for the submission.

\section{Authors' contributions}

$L K, A D, K L$ and $C B$ wrote the manuscript. All authors read and commented on the manuscript and approved submission of the final version.

\section{Funding}

This study was supported by the Munich Excellence Training Initiative for Physician Scientists (Metiphys, to LK), the CPC-M translational funds (German Center for Lung Research (DZL) to AD, CASW, and CB), and the German Cancer Consortium (DKTK to CB). Research in the authors' laboratories is supported by the DFG (GRK 2338 "Targets in Toxicology" to AD and CASW) and the BMBF ("ZiSStrans" 02NUK047C to KL).

This research was funded in part through the $\mathrm{NIH} / \mathrm{NCl}$ Cancer Center Support Grant P30 CA008748.

\section{Availability of data and materials}

Not applicable.

\section{Ethics approval and consent to participate}

Not applicable.

\section{Consent for publication}

Not applicable.

\section{Competing interests}

The authors declare that competing interests do not exist.

\section{Author details}

'Department of Radiation Oncology, University Hospital, LMU Munich, Marchioninistrasse 15, 81377 Munich, Germany. ${ }^{2}$ German Center for Lung
Research (DZL), partner site Munich, Munich, Germany. ${ }^{3}$ German Cancer Consortium (DKTK), partner site Munich, Munich, Germany. ${ }^{4}$ Walther Straub Institute of Pharmacology and Toxicology, Member of the German Center for Lung Research (DZL), Medical Faculty, LMU-Munich, Munich, Germany. ${ }^{5}$ Institute of Lung Biology and Disease, Helmholtz Zentrum München, Munich, Germany. ${ }^{6}$ Department of Internal Medicine V, LMU Munich, Munich, Germany. ${ }^{7}$ Department of Radiation Oncology, Memorial Sloan Kettering Cancer Center, New York, USA. ${ }^{8}$ Research Institute of Clinical Medicine, Tbilisi, Georgia. ${ }^{9}$ Department of Radiation Oncology, Amsterdam University Medical Centers, Amsterdam, Netherlands. ${ }^{10}$ Department of Radiation Oncology (MAASTRO), GROW School for Oncology and Developmental Biology, Maastricht University Medical Centre, Maastricht, the Netherlands.

Received: 1 July 2020 Accepted: 20 August 2020

Published online: 10 September 2020

\section{References}

1. Siegel RL, Miller KD, Jemal A. Cancer statistics, 2019. CA Cancer J Clin. 2019; 69:7-34.

2. Delaney G, Barton M, Jacob S, Jalaludin B. A model for decision making for the use of radiotherapy in lung cancer. Lancet Oncol. 2003;4:120-8.

3. Nestle U, Schimek-Jasch T, Kremp S, Schaefer-Schuler A, Mix M, Küsters A, Tosch M, Hehr T, Eschmann SM, Bultel YP, Hass P. Imagingbased target volume reduction in chemoradiotherapy for locally advanced non-small-cell lung cancer (PET-Plan): a multicentre, open-label, randomised, controlled trial. The Lancet Oncology. 2020;21(4):581-92.

4. Unterrainer M, Eze C, Ilhan H, Marschner S, Roengvoraphoj O, SchmidtHegemann N, Walter F, Kunz W, Af Rosenschöld PM, Jeraj R. Recent advances of PET imaging in clinical radiation oncology. Radiat Oncol. 2020; 15:1-15.

5. Chun S, Hu C, Choy H, Komaki R, Timmerman R, Schild S, Bogart J, Dobelbower M, Bosch W, Galvin J. Comparison of 3-D conformal and intensity modulated radiation therapy outcomes for locally advanced nonsmall cell lung cancer in NRG oncology/RTOG 0617. Int J Radiat Oncol Biol Phys. 2015;93:S1-2.

6. Ling DC, Hess CB, Chen AM, Daly ME. Comparison of toxicity between intensity-modulated radiotherapy and 3-dimensional conformal radiotherapy for locally advanced non-small-cell lung cancer. Clin Lung Cancer. 2016:17:18-23.

7. Finazzi T, Haasbeek CJ, Spoelstra FO, Palacios MA, Admiraal MA, Bruynzeel AM, Slotman BJ, Lagerwaard FJ, Senan S. Clinical outcomes of stereotactic MR-guided adaptive radiation therapy for high-risk lung tumors. Int J Radiat Oncol Biol Phys. 2020;107(2):270-78.

8. De Ruysscher D, Niedermann G, Burnet NG, Siva S, Lee AW, Hegi-Johnson F. Radiotherapy toxicity. Nat Rev Dis Primers. 2019;5:1-20.

9. Kurz C, Buizza G, Landry G, Kamp F, Rabe M, Paganelli C, Baroni G, Reiner M, Keall PJ, van den Berg CA. Medical physics challenges in clinical MR-guided radiotherapy. Radiat Oncol. 2020;15:1-16.

10. Borghaei H, Langer CJ, Gadgeel S, Papadimitrakopoulou VA, Patnaik A, Powell SF, Gentzler RD, Martins RG, Stevenson JP, Jalal SI. 24-month overall survival from KEYNOTE-021 cohort G: Pemetrexed and carboplatin with or without Pembrolizumab as first-line therapy for advanced nonsquamous non-small cell lung Cancer. J Thorac Oncol. 2019;14:124-9.

11. Reck M, Rodríguez-Abreu D, Robinson AG, et al. LBA8_PR - KEYNOTE-024: Pembrolizumab (pembro) vs platinum-based chemotherapy (chemo) as first-line therapy for advanced NSCLC with a PD-L1 tumor proportion score (TPS) $\geq 50 \%$. Abstract presented at ESMO 2016 Congress, October 7 - 11, 2016, Copenhagen, Denmark. Available online: https://cslide.ctimeetingtech. com/library/esmo/browse/itinerary/5286/2016-10-09\#2z94T0v3. Accessed 27 Aug 2020.

12. Paz-Ares L, Luft A, Vicente $D$, Tafreshi A, Gümüş $M$, Mazières J, Hermes $B$, Çay Şenler F, Csőszi T, Fülöp A. Pembrolizumab plus chemotherapy for squamous non-small-cell lung cancer. N Engl J Med. 2018;379:2040-51.

13. Gandhi L, Rodríguez-Abreu D, Gadgeel S, Esteban E, Felip E, De Angelis F, Domine M, Clingan P, Hochmair MJ, Powell SF. Pembrolizumab plus chemotherapy in metastatic non-small-cell lung cancer. N Engl J Med. 2018;378:2078-92.

14. Antonia SJ, Villegas A, Daniel D, Vicente D, Murakami S, Hui R, Kurata T, Chiappori A, Lee KH, de Wit M. Overall survival with durvalumab after chemoradiotherapy in stage III NSCLC. N Engl J Med. 2018;379:2342-50. 
15. Käsmann L, Eze C, Dantes M, Roengvoraphoj O, Niyazi M, Belka C, Manapov F. State of clinical research of radiotherapy/chemoradiotherapy and immune checkpoint inhibitor therapy combinations in solid tumours-a German radiation oncology survey. Eur J Cancer. 2019;108:50-4.

16. Käsmann L, Eze C, Manapov F. Stereotactic body radiation therapy (SBRT) combined with immune check-point inhibition $(\mathrm{ICl})$ in advanced lung cancer: which metastatic site should be irradiated to induce immunogenic cell death?. Int J Radiat Oncol Biol Phys. 2020;108(1):225-6.

17. Mok TS, Wu Y-L, Thongprasert S, Yang C-H, Chu D-T, Saijo N, Sunpaweravong P, Han B, Margono B, Ichinose Y. Gefitinib or carboplatinpaclitaxel in pulmonary adenocarcinoma. N Engl J Med. 2009;361:947-57.

18. Rosell R, Carcereny E, Gervais R, Vergnenegre A, Massuti B, Felip E, Palmero R, Garcia-Gomez R, Pallares C, Sanchez JM. Erlotinib versus standard chemotherapy as first-line treatment for European patients with advanced EGFR mutation-positive non-small-cell lung cancer (EURTAC): a multicentre, open-label, randomised phase 3 trial. Lancet Oncol. 2012;13:239-46.

19. Shaw AT, Kim D-W, Nakagawa K, Seto T, Crinó L, Ahn M-J, De Pas T, Besse B, Solomon BJ, Blackhall F. Crizotinib versus chemotherapy in advanced ALKpositive lung cancer. N Engl J Med. 2013;368:2385-94.

20. Wijsman R, Dankers F, Troost EG, Hoffmann AL, van der Heijden EH, de GeusOei L-F, Bussink J. Comparison of toxicity and outcome in advanced stage non-small cell lung cancer patients treated with intensity-modulated (chemo-) radiotherapy using IMRT or VMAT. Radiother Oncol. 2017;122:295-9.

21. Chao P-J, Lee H-F, Lan J-H, Guo S-S, Ting H-M, Huang Y-J, Chen H-C, Lee TF. Propensity-score-matched evaluation of the incidence of radiation pneumonitis and secondary cancer risk for breast cancer patients treated with IMRTNMAT. Sci Rep. 2017;7:1-9.

22. Wennberg B, Gagliardi G, Sundbom L, Svane G, Lind P. Early response of lung in breast cancer irradiation: radiologic density changes measured by CT and symptomatic radiation pneumonitis. Int J Radiat Oncol Biol Phys. 2002:52:1196-206.

23. Nishioka A, Ogawa Y, Hamada N, Terashima M, Inomata T, Yoshida S. Analysis of radiation pneumonitis and radiation-induced lung fibrosis in breast cancer patients after breast conservation treatment. Oncol Rep. 1999;6:513-20.

24. Keffer S, Guy CL, Weiss E. Fatal radiation pneumonitis: literature review and case series. Adv Radiat Oncol. 2020 Mar. 5(2):238-49.

25. Sun L-M, Leung SW, Wang C-J, Chen H-C, Fang F-M, Huang E-Y, Hsu H-C, Yeh S-A, Hsiung C-Y, Huang DT. Concomitant boost radiation therapy for inoperable non-small-cell lung cancer: preliminary report of a prospective randomized study. Int J Radiat Oncol Biol Phys. 2000;47:413-8.

26. Cannon DM, Mehta MP, Adkison JB, Khuntia D, Traynor AM, Tomé WA, Chappell RJ, Tolakanahalli R, Mohindra P, Bentzen SM. Dose-limiting toxicity after Hypofractionated dose-escalated radiotherapy in non-small-cell lung Cancer. J Clin Oncol. 2013;31:4343.

27. Wurstbauer K, Zehentmayr F, Deutschmann H, Dagn K, Exeli A-K, Kopp P, Porsch P, Maurer B, Studnicka M, Sedlmayer F. DART-bid for loco-regionally advanced NSCLC. Strahlenther Onkol. 2017:193:315-23.

28. Nguyen Q-N, Ly NB, Komaki R, Levy LB, Gomez DR, Chang JY, Allen PK, Mehran RJ, Lu C, Gillin M. Long-term outcomes after proton therapy, with concurrent chemotherapy, for stage II-III inoperable non-small cell lung cancer. Radiother Oncol. 2015;115:367-72.

29. Onishi H, Kuriyama K, Yamaguchi M, Komiyama T, Tanaka S, Araki T, Nishikawa $\mathrm{K}$, Ishihara $\mathrm{H}$. Concurrent two-dimensional radiotherapy and weekly docetaxel in the treatment of stage III non-small cell lung cancer: a good local response but no good survival due to radiation pneumonitis. Lung Cancer Amst Neth. 2003;40:79-84. https://doi.org/10.1016/s0169-5002(02)00532-9.

30. Sejpal S, Komaki R, Tsao A, Chang JY, Liao Z, Wei X, Allen PK, Lu C, Gillin M, Cox JD. Early findings on toxicity of proton beam therapy with concurrent chemotherapy for nonsmall cell lung cancer. Cancer. 2011;117:3004-13.

31. Rehman S, Speirs C, Molotievschi A, Mullen D, Fergus S, DeWees T, Velez M, Bradley J, Robinson C. Evaluating a nomogram for the development of radiation pneumonitis in locally advanced non-small cell lung cancer treated with $3 \mathrm{~d}$ and intensity modulated radiation therapy. Int J Radiat Oncol Biol Phys. 2014;90:S161-2.

32. Zhang T, Zhou Z, Bi N, Wang J, Wang L, Deng L, Feng Q, Liang J, Xiao Z, Chen D. VMAT for Unresectable locally advanced NSCLC does not increase the risk of radiation pneumonitis compared with IMRT. Int J Radiat Oncol Biol Phys. 2019;105:E543.

33. Wu K, Xu X, Li X, Wang J, Zhu L, Chen X, Wang B, Zhang M, Xia B, Ma S. Radiation pneumonitis in lung cancer treated with volumetric modulated arc therapy. J Thorac Dis. 2018;10:6531.
34. Chang JY, Verma V, Li M, Zhang W, Komaki R, Lu C, Allen PK, Liao Z, Welsh $\mathrm{J}$, Lin SH. Proton beam radiotherapy and concurrent chemotherapy for unresectable stage III non-small cell lung cancer: final results of a phase 2 study. JAMA Oncol. 2017;3:e172032.

35. Osti M, Agolli L, Valeriani M, Reverberi C, Bracci S, Marinelli L, De Sanctis V, Cortesi E, Martelli M, De Dominicis C. 30 Gy single dose stereotactic body radiation therapy (SBRT): report on outcome in a large series of patients with lung oligometastatic disease. Lung Cancer. 2018;122:165-70.

36. Nicosia L, Reverberi C, Agolli L, Marinelli L, De Sanctis V, Valeriani M, Osti MF. Long term results of single high dose stereotactic body radiotherapy in the treatment of primary lung tumors. Sci Rep. 2019;9:1-8.

37. Bertolaccini L, Terzi A, Ricchetti F, Alongi F. Surgery or stereotactic ablative radiation therapy: how will be treated operable patients with early stage not small cell lung cancer in the next future? Ann Transl Med. 2015;3(2):25.

38. Park HS, Harder EM, Mancini BR, Decker RH. Central versus peripheral tumor location: influence on survival, local control, and toxicity following stereotactic body radiotherapy for primary non-small-cell lung cancer. J Thorac Oncol. 2015;10:832-7.

39. Zhao Y, Khawandanh E, Thomas S, Zhang S, Dunne EM, Liu M, Schellenberg D. Outcomes of stereotactic body radiotherapy $60 \mathrm{~Gy}$ in 8 fractions when prioritizing organs at risk for central and ultracentral lung tumors. Radiat Oncol. 2020;15:1-13.

40. Guckenberger M, Baier K, Polat B, Richter A, Krieger T, Wilbert J, Mueller G, Flentje M. Dose-response relationship for radiation-induced pneumonitis after pulmonary stereotactic body radiotherapy. Radiother Oncol. 2010;97:65-70.

41. de Jong EE, Guckenberger M, Andratschke N, Dieckmann K, Hoogeman MS, Milder M, Møller DS, Nyeng TB, Tanadini-Lang S, Lartigau E. Variation in current prescription practice of stereotactic body radiotherapy for peripherally located early stage non-small cell lung cancer: recommendations for prescribing and recording according to the ACROP guideline and ICRU report 91. Radiother Oncol. 2020;142:217-23.

42. Kalinauskaite GG, Tinhofer II, Kufeld MM, Kluge AA, Grün AA, Budach W, Senger CC, Stromberger CC. Radiosurgery and fractionated stereotactic body radiotherapy for patients with lung oligometastases. BMC Cancer. 2020;20:1-10.

43. Cox JD, Stetz J, Pajak TF. Toxicity criteria of the radiation therapy oncology group (RTOG) and the European organization for research and treatment of cancer (EORTC). Int J Radiat Oncol Biol Phys. 1995;31:1341-6.

44. National Cancer Institute (US). Cancer Therapy Evaluation Program (2017) Common Terminology Criteria for Adverse Events:(CTCAE). v5. Cancer Therapy Evaluation Program.

45. Wannenmacher M, Debus J, Wenz F. Strahlentherapie. Berlin: SpringerVerlag; 2007.

46. Wang Z, Huo B, Wu Q, Dong L, Fu H, Wang S, Zhang J. The role of procalcitonin in differential diagnosis between acute radiation pneumonitis and bacterial pneumonia in lung cancer patients receiving thoracic radiotherapy. Sci Rep. 2020;10:1-6.

47. Toma CL, Serbescu A, Alexe M, Cervis L, Ionita D, Bogdan MA. The bronchoalveolar lavage pattern in radiation pneumonitis secondary to radiotherapy for breast cancer. Maedica. 2010;5(4):250-7.

48. Schröder C, Engenhart-Cabillic R, Vorwerk H, Schmidt M, Huhnt W, Blank E, Sidow D, Buchali A. Changes in pulmonary function and influencing factors after high-dose intrathoracic radio (chemo) therapy. Strahlenther Onkol. 2017;193:125-31.

49. Guerra JLL, Gomez D, Zhuang Y, Levy LB, Eapen G, Liu H, Mohan R, Komaki $\mathrm{R}$, Cox JD, Liao Z. Change in diffusing capacity after radiation as an objective measure for grading radiation pneumonitis in patients treated for non-small-cell lung cancer. Int J Radiat Oncol Biol Phys. 2012;83:1573-9.

50. Davis SD, Yankelevitz DF, Henschke Cl. Radiation effects on the lung: clinical features, pathology, and imaging findings. AJR Am J Roentgenol. 1992;159: 1157-64.

51. Thomas R, Chen YH, Hatabu H, Mak RH, Nishino M. Radiographic patterns of symptomatic radiation pneumonitis in lung cancer patients: Imaging predictors for clinical severity and outcome. Lung Cancer. 2020;145:132-9.

52. Ikezoe J, Takashima S, Morimoto S, Kadowaki K, Takeuchi N, Yamamoto T, Nakanishi K, Isaza M, Arisawa J, Ikeda H. CT appearance of acute radiationinduced injury in the lung. Am J Roentgenol. 1988;150:765-70.

53. De Wever W, Meersschaert J, Coolen J, Verbeken E, Verschakelen JA. The crazy-paving pattern: a radiological-pathological correlation. Insights Imaging. 2011;2:117-32. 
54. Ronden MI, Palma D, Slotman BJ, Senan S. Brief report on radiological changes following stereotactic ablative radiotherapy (SABR) for early-stage lung tumors: a pictorial essay. J Thorac Oncol. 2018;13:855-62.

55. Dahele M, Palma D, Lagerwaard F, Slotman B, Senan S. Radiological changes after stereotactic radiotherapy for stage I lung cancer. J Thorac Oncol. 2011; 6:1221-8.

56. Benveniste MF, Gomez D, Carter BW, Betancourt Cuellar SL, Shroff GS, Benveniste APA, Odisio EG, Marom EM. Recognizing radiation therapyrelated complications in the chest. Radiographics. 2019;39:344-66.

57. Epler GR, Kelly EM. Systematic review of postradiotherapy bronchiolitis obliterans organizing pneumonia in women with breast cancer. Oncologist. 2014;19:1216.

58. Choi YW, Munden RF, Erasmus JJ, Joo Park K, Chung WK, Jeon SC, Park C-K. Effects of radiation therapy on the lung: radiologic appearances and differential diagnosis. Radiographics. 2004:24:985-97.

59. Cornelissen R, Senan S, Antonisse IE, Liem H, Tan YK, Rudolphus A, Aerts JG. Bronchiolitis obliterans organizing pneumonia (BOOP) after thoracic radiotherapy for breast carcinoma. Radiat Oncol. 2007;2:1-5.

60. Murofushi KN, Oguchi M, Gosho M, Kozuka T, Sakurai H. Radiation-induced bronchiolitis obliterans organizing pneumonia (BOOP) syndrome in breast cancer patients is associated with age. Radiat Oncol. 2015;10:103.

61. Dileto $\mathrm{CL}$, Travis EL. Fibroblast radiosensitivity in vitro and lung fibrosis in vivo: comparison between a fibrosis-prone and fibrosis-resistant mouse strain. Radiat Res. 1996;146:61-7.

62. Iwata H, Murai T, Shibamoto Y. Radiation response of the normal lung tissue and lung tumors. In: Advances in radiation oncology in lung Cancer. Berlin: Springer; 2011. p. 119-28.

63. Tsoutsou PG, Koukourakis MI. Radiation pneumonitis and fibrosis: mechanisms underlying its pathogenesis and implications for future research. Int J Radiat Oncol Biol Phys. 2006;66:1281-93.

64. Wirsdörfer F, Jendrossek V. Modeling DNA damage-induced pneumopathy in mice: insight from danger signaling cascades. Radiat Oncol. 2017;12:142.

65. de Leve S, Wirsdörfer F, Cappuccini F, Schütze A, Meyer AV, Röck K, Thompson LF, Fischer JW, Stuschke M, Jendrossek V. Loss of CD73 prevents accumulation of alternatively activated macrophages and the formation of prefibrotic macrophage clusters in irradiated lungs. FASEB J. 2017;31:2869_ 80.

66. Hansel $C$, Jendrossek V, Klein D. Cellular senescence in the lung: the central role of senescent epithelial cells. Int J Mol Sci. 2020;21:3279.

67. Robbins ME, Diz DI. Pathogenic role of the renin-angiotensin system in modulating radiation-induced late effects. Int J Radiat Oncol Biol Phys. 2006; 64:6-12.

68. Fleckenstein K, Gauter-Fleckenstein B, Jackson IL, Rabbani Z, Anscher M, Vujaskovic Z. Using biological markers to predict risk of radiation injury. Seminars in radiation oncology. 2007;(2):89-98. https://doi.org/10.1016/j. semradonc.2006.11.004.

69. Chiang C-S, Liu W-C, Jung S-M, Chen F-H, Wu C-R, McBride WH, Lee C-C, Hong $\mathrm{J}-\mathrm{H}$. Compartmental responses after thoracic irradiation of mice: strain differences. Int J Radiat Oncol Biol Phys. 2005:62:862-71.

70. Citrin DE, Shankavaram U, Horton JA, Shield W III, Zhao S, Asano H, White A, Sowers A, Thetford A, Chung EJ. Role of type II pneumocyte senescence in radiation-induced lung fibrosis. J Natl Cancer Inst. 2013;105:1474-84.

71. Hall EJ, Giaccia AJ. Radiobiology for the Radiologist, 8th Ed. Philadelphia: Lippincott Williams \& Wilkins; 2018.

72. Lauber K, Ernst A, Orth M, Herrmann M, Belka C. Dying cell clearance and its impact on the outcome of tumor radiotherapy. Front Oncol. 2012;2:116.

73. Coppé J-P, Desprez P-Y, Krtolica A, Campisi J. The senescence-associated secretory phenotype: the dark side of tumor suppression. Annu Rev Pathol Mech Dis. 2010:5:99-118.

74. Desai TJ, Brownfield DG, Krasnow MA. Alveolar progenitor and stem cells in lung development, renewal and cancer. Nature. 2014;507:190-4.

75. Trott KR, Herrmann T, Kasper M. Target cells in radiation pneumopathy. Int J Radiat Oncol Biol Phys. 2004;58:463-9.

76. Fleckenstein K, Zgonjanin L, Chen L, Rabbani Z, Jackson IL, Thrasher B, Kirkpatrick J, Foster WM, Vujaskovic Z. Temporal onset of hypoxia and oxidative stress after pulmonary irradiation. Int J Radiat Oncol Biol Phys. 2007;68:196-204.

77. Ding N-H, Jian Li J, Sun L-Q. Molecular mechanisms and treatment of radiation-induced lung fibrosis. Curr Drug Targets. 2013;14:1347-56.

78. Giuranno L, lent J, De Ruysscher D, Vooijs MA. Radiation-induced lung injury (RILI). Front Oncol. 2019:9:877.
79. Zhang B, Wang Y, Pang X, Su Y, Ai G, Wang T. ER stress induced by ionising radiation in IEC-6 cells. Int J Radiat Biol. 2010;86:429-35.

80. Ryter SW, Kim HP, Hoetzel A, Park JW, Nakahira K, Wang X, Choi AM. Mechanisms of cell death in oxidative stress. Antioxid Redox Signal. 2007;9: 49-89.

81. Jack Cl, Bottier B, Jackson MJ, Cassapi L, Fraser WD, Hind CR. Indicators of free radical activity in patients developing radiation pneumonitis. Int J Radiat Oncol Biol Phys. 1996;34:149-54.

82. Arpin D, Perol D, Blay J-Y, Falchero L, Claude L, Vuillermoz-Blas S, MartelLafay I, Ginestet C, Alberti L, Nosov D. Early variations of circulating interleukin-6 and interleukin-10 levels during thoracic radiotherapy are predictive for radiation pneumonitis. J Clin Oncol. 2005;23:8748-56.

83. Chen Y, Williams J, Ding I, Hernady E, Liu W, Smudzin T, Finkelstein JN, Rubin P, Okunieff P. Radiation pneumonitis and early circulatory cytokine markers. Seminars in radiation oncology. 2002;12(1):26-33. https://doi.org/ 10.1053/srao.2002.31360

84. Kühlmann UC, Chwieralski CE, Reinhold D, Welte T, Bühling F. Radiationinduced matrix production of lung fibroblasts is regulated by interleukin-8. Int J Radiat Biol. 2009:85:138-43.

85. Wirsdörfer $F$, Jendrossek $V$. The role of lymphocytes in radiotherapy-induced adverse late effects in the lung. Front Immunol. 2016;7:591.

86. Kainthola A, Haritwal T, Tiwari M, Gupta N, Parvez S, Tiwari M, Prakash H, Agrawala PK. Immunological aspect of radiation-induced pneumonitis, current treatment strategies, and future prospects. Front Immunol. 2017;8: 506.

87. McKelvey KJ, Hudson AL, Back M, Eade T, Diakos Cl. Radiation, inflammation and the immune response in cancer. Mamm Genome. 2018;29:843-65.

88. Vujaskovic Z, Anscher MS, Feng Q-F, Rabbani ZN, Amin K, Samulski TS, Dewhirst MW, Haroon ZA. Radiation-induced hypoxia may perpetuate late normal tissue injury. Int J Radiat Oncol Biol Phys. 2001;50:851-5.

89. Liu Y, Xia T, Zhang W, Zhong Y, Zhang L, Wang X, Yu H. Variations of circulating endothelial progenitor cells and transforming growth factorbeta-1 (TGF- $\beta$ 1) during thoracic radiotherapy are predictive for radiation pneumonitis. Radiat Oncol. 2013:8:189.

90. Molteni A, Wolfe LF, Ward WF, Hsin Ts'ao C, Brizio Molteni L, Veno P, Fish BL, Taylor JM, Quintanilla N, Herndon B. Effect of an angiotensin II receptor blocker and two angiotensin converting enzyme inhibitors on transforming growth factor- $\beta$ (TGF- $\beta$ ) and a-Actomyosin (a SMA), important mediators of radiationinduced pneumopathy and lung fibrosis. Curr Pharm Des. 2007;13:1307-16.

91. Hata A, Chen Y-G. TGF- $\beta$ signaling from receptors to Smads. Cold Spring Harb Perspect Biol. 2016;8:a022061

92. Dewen LYSLW, Yabin P, Junjie JMM. Studies on the expression of Smad3, Smad4 and Smad7 in rats with radiation pulmonary fibrosis [J]. J Radiat Res Radiat Process. 2004;3. Available online: http://en.cnki.com.cn/Article_en/ CJFDTotal-FYFG200403004.htm. Accessed 27 Aug 2020

93. Ryu S-Y, Do S-H, Chung J-Y, Kim T-H, Kim S-H, Choi C-Y, Jeong K-S, Park S-J. Activation of MAP kinases during progression of radiation-induced pneumonitis in rats. Hum Exp Toxicol. 2011;30:876-83.

94. Raghu G, Masta S, Meyers D, Narayanan AS. Growth factor-J31-3. Am Rev Respir Dis. 1989;140:95-100.

95. Ignotz RA, Massague J. Transforming growth factor-beta stimulates the expression of fibronectin and collagen and their incorporation into the extracellular matrix. J Biol Chem. 1986:261:4337-45.

96. Luo Y, Xu W, Chen H, Warburton D, Dong R, Qian B, Selman M, Gauldie J, Kolb M, Shi W. A novel profibrotic mechanism mediated by TGF stimulated collagen prolyl hydroxylase expression in fibrotic lung mesenchymal cells. J Pathol. 2015;236:384-94.

97. Rubin P, Johnston CJ, Williams JP, McDonald S, Finkelstein JN. A perpetual cascade of cytokines postirradiation leads to pulmonary fibrosis. Int J Radiat Oncol Biol Phys. 1995;33:99-109.

98. Barcellos-Hoff M, Dix TA. Redox-mediated activation of latent transforming growth factor-beta 1. Mol Endocrinol. 1996;10:1077-83.

99. Tomasek JJ, Gabbiani G, Hinz B, Chaponnier C, Brown RA. Myofibroblasts and mechano-regulation of connective tissue remodelling. Nat Rev Mol Cell Biol. 2002;3:349-63.

100. Kendall RT, Feghali-Bostwick CA. Fibroblasts in fibrosis: novel roles and mediators. Front Pharmacol. 2014;5:123

101. Vogelius IR, Bentzen SM. A literature-based meta-analysis of clinical risk factors for development of radiation induced pneumonitis. Acta Oncol. 2012;51:975-83. 
102. Jin H, Tucker SL, Liu HH, Wei X, Yom SS, Wang S, Komaki R, Chen Y, Marte MK, Mohan R. Dose-volume thresholds and smoking status for the risk of treatment-related pneumonitis in inoperable non-small cell lung cancer treated with definitive radiotherapy. Radiother Oncol. 2009;91:427-32.

103. Bradley JD, Hope A, El Naqa I, Apte A, Lindsay PE, Bosch W, Matthews J, Sause W, Graham MV, Deasy JO. A nomogram to predict radiation pneumonitis, derived from a combined analysis of RTOG 9311 and institutional data. Int J Radiat Oncol Biol Phys. 2007;69:985-92.

104. Wen J, Liu H, Wang Q, Liu Z, Li Y, Xiong H, Xu T, Li P, Wang L-E, Gomez DR. Genetic variants of the LIN28B gene predict severe radiation pneumonitis in patients with non-small cell lung cancer treated with definitive radiation therapy. Eur J Cancer. 2014;50:1706-16.

105. Ball DL, Fisher RJ, Burmeister BH, Poulsen MG, Graham PH, Penniment MG, Vinod SK, Krawitz HE, Joseph DJ, Wheeler GC. The complex relationship between lung tumor volume and survival in patients with non-small cell lung cancer treated by definitive radiotherapy: a prospective, observational prognostic factor study of the trans-Tasman radiation oncology group (TROG 99.05). Radiother Oncol. 2013;106:305-11.

106. Rancati T, Ceresoli GL, Gagliardi G, Schipani S, Cattaneo GM. Factors predicting radiation pneumonitis in lung cancer patients: a retrospective study. Radiother Oncol. 2003;67:275-83.

107. Kimura T, Togami T, Takashima H, Nishiyama Y, Ohkawa M, Nagata Y. Radiation pneumonitis in patients with lung and mediastinal tumours: a retrospective study of risk factors focused on pulmonary emphysema. $\mathrm{Br} \mathrm{J}$ Radiol. 2012:85:135-41.

108. Takeda A, Kunieda E, Ohashi T, Aoki Y, Oku Y, Enomoto T, Nomura K, Sugiura M. Severe COPD is correlated with mild radiation pneumonitis following stereotactic body radiotherapy. Chest. 2012;141:858-66.

109. Finazzi T, Ronden-Kianoush MI, Spoelstra FO, Nossent EJ, Nijman SF, Bahce I, Dickhoff C, Senan S. Stereotactic ablative radiotherapy in patients with early-stage non-small cell lung cancer and co-existing interstitial lung disease. Acta Oncol. 2020;59:569-73.

110. Goodman CD, Nijman SF, Senan S, Nossent EJ, Ryerson CJ, Dhaliwal I, Qu M, Laba J, Rodrigues G, Palma DA. A Primer on Interstitial Lung Disease and Thoracic Radiation. J Thorac Oncol. 2020;15(6):902-13.

111. Bahig H, Filion E, Vu T, Chalaoui J, Lambert L, Roberge D, Gagnon M, Fortin B, Béliveau-Nadeau D, Mathieu D. Severe radiation pneumonitis after lung stereotactic ablative radiation therapy in patients with interstitial lung disease. Pract Radiat Oncol. 2016;6:367-74.

112. Takeda A, Ohashi T, Kunieda E, Enomoto T, Sanuki N, Takeda T, Shigematsu $N$. Early graphical appearance of radiation pneumonitis correlates with the severity of radiation pneumonitis after stereotactic body radiotherapy (SBRT) in patients with lung tumors. Int J Radiat Oncol Biol Phys. 2010;77:685-90.

113. Ueki N, Matsuo Y, Togashi Y, Kubo T, Shibuya K, lizuka Y, Mizowaki T, Togashi K, Mishima M, Hiraoka M. Impact of pretreatment interstitial lung disease on radiation pneumonitis and survival after stereotactic body radiation therapy for lung cancer. J Thorac Oncol. 2015;10:116-25.

114. Chen H, Senan S, Nossent EJ, Boldt RG, Warner A, Palma DA, Louie AV. Treatment-related toxicity in patients with early-stage non-small cell lung cancer and coexisting interstitial lung disease: a systematic review. Int J Radiat Oncol Biol Phys. 2017:98:622-31.

115. De Ruysscher D, Faivre-Finn C, Moeller D, Nestle U, Hurkmans CW, Le Péchoux C, Belderbos J, Guckenberger M, Senan S, Group L. European Organization for Research and Treatment of Cancer (EORTC) recommendations for planning and delivery of high-dose, high precision radiotherapy for lung cancer. Radiother Oncol. 2017;124:1-10.

116. Washko GR, Hunninghake GM, Fernandez IE, Nishino M, Okajima Y, Yamashiro T, Ross JC, Estépar RSJ, Lynch DA, Brehm JM. Lung volumes and emphysema in smokers with interstitial lung abnormalities. N Engl J Med. 2011:364:897-906

117. Brown S-AW, Padilla M, Mhango G, Powell C, Salvatore M, Henschke C, Yankelevitz D, Sigel K, De-Torres JP, Wisnivesky J. Interstitial lung abnormalities and lung cancer risk in the National Lung Screening Trial. Chest. 2019;156:1195-203.

118. Putman RK, Hatabu H, Araki T, Gudmundsson G, Gao W, Nishino M, Okajima Y, Dupuis J, Latourelle JC, Cho MH. Association between interstitial lung abnormalities and all-cause mortality. Jama. 2016;315:672-81.

119. Palma DA, Chen $H$, Bahig H, Gaede S, Harrow S, Laba JM, Qu XM, Rodrigues $G B$, Yaremko BP, Yu E. Assessment of precision irradiation in early non-small cell lung cancer and interstitial lung disease (ASPIRE-ILD): study protocol for a phase II trial. BMC Cancer. 2019;19:1206.
120. Nakamura T, Fuwa N, Kodaira T, Tachibana H, Tomoda T, Nakahara R, Inokuchi $\mathrm{H}$. Clinical outcome of stage III non-small-cell lung cancer patients after definitive radiotherapy. Lung. 2008;186:91-6.

121. Parker SM, Siochi RA, Wen S, Mattes MD. Impact of tumor size on local control and pneumonitis after stereotactic body radiation therapy for lung tumors. Pract Radiat Oncol. 2019:9:e90-7.

122. Meng Y, Yang H, Wang W, Tang X, Jiang C, Shen Y, Luo W. Excluding PTV from lung volume may better predict radiation pneumonitis for intensity modulated radiation therapy in lung cancer patients. Radiat Oncol. 2019;14: 7.

123. De Petris L, Lax I, Sirzén F, Friesland S. Role of gross tumor volume on outcome and of dose parameters on toxicity of patients undergoing chemoradiotherapy for locally advanced non-small cell lung cancer. Med Oncol. 2005;22:375-81

124. Palma DA, Senan S, Tsujino K, Barriger RB, Rengan R, Moreno M, Bradley JD, Kim TH, Ramella S, Marks LB. Predicting radiation pneumonitis after chemoradiation therapy for lung cancer: an international individual patient data meta-analysis. Int J Radiat Oncol Biol Phys. 2013;85:444-50.

125. Yorke ED, Jackson A, Kuo LC, Ojo A, Panchoo K, Adusumilli P, Zauderer MG, Rusch WW, Shepherd A, Rimner A. Heart dosimetry is correlated with risk of radiation pneumonitis after lung-sparing hemithoracic pleural intensity modulated radiation therapy for malignant pleural mesothelioma. Int J Radiat Oncol Biol Phys. 2017;99:61-9.

126. Dang J, Li G, Zang S, Zhang S, Yao L. Comparison of risk and predictors for early radiation pneumonitis in patients with locally advanced non-small cell lung cancer treated with radiotherapy with or without surgery. Lung Cancer. 2014;86:329-33.

127. Huang EX, Hope AJ, Lindsay PE, Trovo M, El Naqa I, Deasy JO, Bradley JD. Heart irradiation as a risk factor for radiation pneumonitis. Acta Oncol. 2011; 50:51-60.

128. Dang J, Li G, Zang S, Zhang S, Yao L. Risk and predictors for early radiation pneumonitis in patients with stage III non-small cell lung cancer treated with concurrent or sequential chemoradiotherapy. Radiat Oncol. 2014;9:172.

129. Bledsoe TJ, Nath SK, Decker RH. Radiation pneumonitis. Clin Chest Med. 2017;38:201-8

130. Jeremić B, Miličić B, Milisavljevic S. Toxicity of concurrent hyperfractionated radiation therapy and chemotherapy in locally advanced (stage III) nonsmall cell lung cancer (NSCLC): single institution experience in 600 patients. Clin Transl Oncol. 2012;14:613-8.

131. Fujimori K, Yokoyama A, Kurita Y, Uno K, Saijo N. Paclitaxel-induced cellmediated hypersensitivity pneumonitis. Oncology. 1998;55:340-4.

132. Taghian AG, Assaad SI, Niemierko A, Kuter I, Younger J, Schoenthaler R, Roche M, Powell SN. Risk of pneumonitis in breast cancer patients treated with radiation therapy and combination chemotherapy with paclitaxel. J Natl Cancer Inst. 2001;93:1806-11.

133. Bielopolski D, Evron E, Moreh-Rahav O, Landes M, Stemmer SM, Salamon F. Paclitaxel-induced pneumonitis in patients with breast cancer: case series and review of the literature. J Chemother. 2017;29:113-7.

134. Aupérin $A$, Le Péchoux C, Rolland E, Curran WJ, Furuse $K$, Fournel $P$, Belderbos J, Clamon G, Ulutin HC, Paulus R. Meta-analysis of concomitant versus sequential radiochemotherapy in locally advanced non-small-cell lung cancer. In: Database of abstracts of reviews of effects (DARE): quality assessed reviews [internet]. York: Centre for Reviews and Dissemination; 2010.

135. Zhang X-J, Sun J-G, Sun J, Ming H, Wang X-X, Wu L, Chen Z-T. Prediction of radiation pneumonitis in lung cancer patients: a systematic review. J Cancer Res Clin Oncol. 2012;138:2103-16.

136. Thor M, Deasy J, lyer A, Bendau E, Fontanella A, Apte A, Yorke E, Rimner A, Jackson A. Toward personalized dose-prescription in locally advanced nonsmall cell lung cancer: validation of published normal tissue complication probability models. Radiother Oncol. 2019;138:45-51.

137. Yamashita H, Takahashi W, Haga A, Nakagawa K. Radiation pneumonitis after stereotactic radiation therapy for lung cancer. World J Radiol. 2014;6: 708.

138. Kong F, Zhang H, Liu Y, Yao H, Cerra-Franco A, Shiue K, Vile D, Wang W, Langer M, Watson G. Radiation to the immune system may be an important risk factor for long-term survival after SBRT in early stage non-small cell lung Cancer: a role of RT plan optimization. Int J Radiat Oncol Biol Phys. 2018; 102:e689-90.

139. Zhao J, Yorke ED, Li L, Kavanagh BD, Li XA, Das S, Miften M, Rimner A Campbell J, Xue J. Simple factors associated with radiation-induced lung 
toxicity after stereotactic body radiation therapy of the thorax: a pooled analysis of 88 studies. Int J Radiat Oncol Biol Phys. 2016;95:1357-66.

140. Ritter TA, Matuszak M, Chetty IJ, Mayo CS, Wu J, lyengar P, Weldon M, Robinson C, Xiao Y, Timmerman RD. Application of critical volume-dose constraints for stereotactic body radiation therapy in NRG radiation therapy trials. Int J Radiat Oncol Biol Phys. 2017;98:34-6.

141. Videtic G, Singh A, Chang J, Le Q, Parker W, Olivier K. A randomized phase II study comparing 2 stereotactic body radiation therapy (SBRT) schedules for medically inoperable patients with stage I peripheral non-small cell lung cancer. Radiation therapy oncology group 0915. Philadelphie: Radiat Ther Oncol Group; 2014.

142. Bezjak A, Bradley J, Gaspar L, Robert D, Papiez L, Gore E. Seamless phase I/II study of stereotactic lung radiotherapy (SBRT) for early stage, centrally located, non-small cell lung cancer (NSCLC) in medically inoperable patients. RTOG. 2012:813:1-75.

143. Wirsdörfer F, De Leve S, Jendrossek V. Combining radiotherapy and immunotherapy in lung cancer: can we expect limitations due to altered normal tissue toxicity? Int J Mol Sci. 2019;20:24.

144. Manapov F, Roengvoraphoj O, Dantes M, Marschner S, Li M, Eze C. Pneumonitis in irradiated lungs after nivolumab: a brief communication and review of the literature. J Immunother. 2018;41:96-9.

145. Tian S, Switchenko JM, Buchwald ZS, Patel PR, Shelton JW, Kahn SE, Pillai RN, Steuer CE, Owonikoko TK, Behera M, Curran WJ. Lung Stereotactic Body Radiation Therapy and Concurrent Immunotherapy: A Multicenter Safety and Toxicity Analysis. Int J Radiat Oncol Biol Phys. 2020;108(1):304-13.

146. McGovern K, Ghaly M, Esposito M, Barnaby K, Seetharamu N. Radiation recall pneumonitis in the setting of immunotherapy and radiation: a focused review. Future Sci OA. 2019:5:FSO378.

147. von Reibnitz D, Chaft JE, Wu AJ, Samstein R, Hellmann MD, Plodkowski AJ, Zhang Z, Shi W, Dick-Godfrey R, Panchoo KH. Safety of combining thoracic radiation therapy with concurrent versus sequential immune checkpoint inhibition. Adv Radiat Oncol. 2018;3:391-8.

148. Bang A, Wilhite TJ, Pike LR, Cagney DN, Aizer AA, Taylor A, Spektor A, Krishnan M, Ott PA, Balboni TA. Multicenter evaluation of the tolerability of combined treatment with PD-1 and CTLA-4 immune checkpoint inhibitors and palliative radiation therapy. Int J Radiat Oncol Biol Phys. 2017;98:344-51.

149. Levy A, Massard C, Soria J-C, Deutsch E. Concurrent irradiation with the antiprogrammed cell death ligand-1 immune checkpoint blocker durvalumab: single Centre subset analysis from a phase 1/2 trial. Eur J Cancer. 2016;68: 156-62.

150. Jabbour SK, Berman AT, Decker RH, Lin Y, Feigenberg SJ, Gettinger SN, Aggarwal C, Langer CJ, Simone CB, Bradley JD, Aisner J. Phase 1 Trial of Pembrolizumab Administered Concurrently With Chemoradiotherapy for Locally Advanced Non-Small Cell Lung Cancer: A Nonrandomized Controlled Trial. JAMA oncology. 2020;6(6):848-55. https://doi.org/10.1001/ jamaoncol.2019.6731

151. Shaverdian N, Thor M, Shepherd AF, Offin MD, Jackson A, Wu AJ, Gelblum DY, Yorke ED, Simone CB, Chaft JE, Hellmann MD. Radiation pneumonitis in lung cancer patients treated with chemoradiation plus durvalumab. Cancer Med. 2020;9(13):4622-31.

152. Naidoo J, Page D, Li B, Connell L, Schindler K, Lacouture M, Postow M, Wolchok J. Toxicities of the anti-PD-1 and anti-PD-L1 immune checkpoint antibodies. Ann Oncol. 2015;26:2375-91.

153. Käsmann L, Eze C, Taugner J, Roengvoraphoj O, Belka C, Manapov F. Implementation of durvalumab maintenance treatment after concurrent chemoradiotherapy in inoperable stage III non-small cell lung cancer (NSCLC) - a German radiation oncology survey. Transl Lung Cancer Res. 2020;9:288.

154. Theelen WSME, Peulen HMU, Lalezari F, van der Noort V, de Vries JF, JGJV A, Dumoulin DW, Bahce I, Niemeijer A-LN, de Langen AJ, Monkhorst K, Baas P. Effect of Pembrolizumab after stereotactic body radiotherapy vs Pembrolizumab alone on tumor response in patients with advanced nonsmall cell lung Cancer: results of the PEMBRO-RT phase 2 randomized clinical TrialPembrolizumab alone vs after stereotactic body radiotherapy in patients with advanced NSCLCPembrolizumab alone vs after stereotactic body radiotherapy in patients with advanced NSCLC. JAMA Oncol. 2019. https://doi.org/10.1001/jamaoncol.2019.1478.

155. Gao F, Fish BL, Moulder JE, Jacobs ER, Medhora M. Enalapril mitigates radiation-induced pneumonitis and pulmonary fibrosis if started 35 days after whole-thorax irradiation. Radiat Res. 2013;180:546-52.
156. Medhora M, Gao F, Jacobs ER, Moulder JE. Radiation damage to the lung: mitigation by angiotensin-converting enzyme (ACE) inhibitors. Respirology. 2012;17:66-71.

157. Li YS, Ni SY, Meng Y, Shi XL, Zhao XW, Luo HH, Li X. Angiotensin II facilitates fibrogenic effect of TGF- $\beta 1$ through enhancing the down-regulation of BAMBI caused by LPS: a new pro-fibrotic mechanism of angiotensin II. PLoS One. 2013;8(10):e76289.

158. Hautmann MB, Thompson MM, Swartz EA, Olson EN, Owens GK. Angiotensin II-induced stimulation of smooth muscle a-actin expression by serum response factor and the homeodomain transcription factor MHox. Circ Res. 1997:81:600-10.

159. Cohen EP, Bedi M, Irving AA, Jacobs E, Tomic R, Klein J, Lawton CA, Moulder JE. Mitigation of late renal and pulmonary injury after hematopoietic stem cell transplantation. Int J Radiat Oncol Biol Phys. 2012;83:292-6.

160. Antonadou D, Petridis A, Synodinou M, Throuvalas N, Bolanos N, Veslemes $M$, Sagriotis A. Amifostine reduces radiochemotherapy-induced toxicities in patients with locally advanced non-small cell lung cancer. Seminars in oncology. 2003;(18):2-9. https://doi.org/10.1053/j.seminoncol.2003.11.008.

161. Mell LK, Malik R, Komaki R, Movsas B, Swann RS, Langer C, Antonadou D, Koukourakis M, Mundt AJ. Effect of amifostine on response rates in locally advanced non-small-cell lung cancer patients treated on randomized controlled trials: a meta-analysis. Int J Radiat Oncol Biol Phys. 2007;68:111-8.

162. Antonadou D, Throuvalas N, Petridis A, Bolanos N, Sagriotis A, Synodinou M. Effect of amifostine on toxicities associated with radiochemotherapy in patients with locally advanced non-small-cell lung cancer. Int J Radiat Oncol Biol Phys. 2003:57:402-8.

163. Komaki R, Lee JS, Milas L, Lee HK, Fossella FV, Herbst RS, Allen PK, Liao Z, Stevens CW, Lu C. Effects of amifostine on acute toxicity from concurrent chemotherapy and radiotherapy for inoperable non-small-cell lung cancer: report of a randomized comparative trial. Int J Radiat Oncol Biol Phys. 2004;58:1369-77.

164. Devine A, Marignol L. Potential of amifostine for chemoradiotherapy and radiotherapy-associated toxicity reduction in advanced NSCLC: a metaanalysis. Anticancer Res. 2016;36:5-12.

165. Antonadou D, Coliarakis N, Synodinou M, Athanassiou H, Kouveli A, Verigos C, Georgakopoulos G, Panoussaki K, Karageorgis P, Throuvalas N. Randomized phase III trial of radiation treatment土amifostine in patients with advancedstage lung cancer. Int J Radiat Oncol Biol Phys. 2001;51:915-22.

166. Movsas B, Scott C, Langer C, Werner-Wasik M, Nicolaou N, Komaki R, Machtay M, Smith C, Axelrod R, Sarna L. Randomized trial of amifostine in locally advanced non-small-cell lung cancer patients receiving chemotherapy and hyperfractionated radiation: radiation therapy oncology group trial 98-01. J Clin Oncol. 2005;23:2145-54.

167. King M, Joseph S, Albert A, Thomas TV, Nittala MR, Woods WC, Vijayakumar S, Packianathan S. Use of Amifostine for Cytoprotection during radiation therapy: a review. Oncology. 2020;98:61-80.

168. Sasse AD, de Oliveira Clark LG, Sasse EC, Clark OAC. Amifostine reduces side effects and improves complete response rate during radiotherapy: results of a meta-analysis. Int J Radiat Oncol Biol Phys. 2006;64:784-91.

169. Pagel J, Mohorn M, Kloetzer K, Fleck M, Wendt T. Inhalative versus systemische Pneumonitisprophylaxe bei Thoraxbestrahlungen. Strahlenther Onkol. 1998;174:25-9.

170. Henkenberens C, Janssen S, Lavae-Mokhtari M, Leni K, Meyer A, Christiansen $\mathrm{H}$, Bremer M, Dickgreber N. Inhalative steroids as an individual treatment in symptomatic lung cancer patients with radiation pneumonitis grade II after radiotherapy-a single-Centre experience. Radiat Oncol. 2016;11:12.

171. Rube C (2002) Wilfert F, Uthe D, Schmid KW, Knoop R, Willich N, Schuck A, Rube C. Modul Radiat-Induc tumour necrosis factor alpha TNF-alpha expr lung tissue Pentoxifylline Radiother Oncol 64:177-187.

172. Ozturk B, Egehan I, Atavci S, Kitapci M. Pentoxifylline in prevention of radiation-induced lung toxicity in patients with breast and lung cancer: a double-blind randomized trial. Int J Radiat Oncol Biol Phys. 2004;58:213-9.

173. Kwon H-C, Kim S-K, Chung W-K, Cho M-J, Kim J-S, Kim J-S, Moon S-R, Park $W-Y, A h n$ S-J, Oh Y-K. Effect of pentoxifylline on radiation response of nonsmall cell lung cancer: a phase III randomized multicenter trial. Radiother Oncol. 2000;56:175-9.

174. Misirlioglu CH, Demirkasimoglu T, Kucukplakci B, Sanri E, Altundag K. Pentoxifylline and alpha-tocopherol in prevention of radiation-induced lung toxicity in patients with lung cancer. Med Oncol. 2007:24:308-11.

175. Flechsig P, Dadrich M, Bickelhaupt S, Jenne J, Hauser K, Timke C, Peschke P, Hahn EW, Gröne H-J, Yingling J. LY2109761 attenuates radiation-induced 
pulmonary murine fibrosis via reversal of TGF- $\beta$ and BMP-associated proinflammatory and proangiogenic signals. Clin Cancer Res. 2012;18:3616-27.

176. Dadrich M, Nicolay NH, Flechsig P, Bickelhaupt S, Hoeltgen L, Roeder F, Hauser K, Tietz A, Jenne J, Lopez R. Combined inhibition of TGF $\beta$ and PDGF signaling attenuates radiation-induced pulmonary fibrosis. Oncoimmunology. 2016:5:e1123366.

177. Kelley RK, Gane E, Assenat E, Siebler J, Galle PR, Merle P, Hourmand IO, Cleverly A, Zhao Y, Gueorguieva I, Lahn M. A phase 2 study of galunisertib (TGF- $\beta 1$ receptor type I inhibitor) and sorafenib in patients with advanced hepatocellular carcinoma. Clinical and translational gastroenterology. 2019; 10(7):e00056.

178. Knüppel L, Ishikawa Y, Aichler M, Heinzelmann K, Hatz R, Behr J, Walch A, Bächinger HP, Eickelberg O, Staab-Weijnitz CA. A novel antifibrotic mechanism of nintedanib and pirfenidone. Inhibition of collagen fibril assembly. Am J Respir Cell Mol Biol. 2017;57:77-90.

179. Kwapiszewska G, Gungl A, Wilhelm J, Marsh LM, Puthenparampil HT, Sinn K, Didiasova M, Klepetko W, Kosanovic D, Schermuly RT, Wujak L. Transcriptome profiling reveals the complexity of pirfenidone effects in idiopathic pulmonary fibrosis. Eur Respir J. 2018;52(5):1800564. https://doi. org/10.1183/13993003.00564-2018.

180. Jin J, Togo S, Kadoya K, Tulafu M, Namba Y, Iwai M, Watanabe J, Nagahama K, Okabe T, Hidayat M. Pirfenidone attenuates lung fibrotic fibroblast responses to transforming growth factor- $\beta 1$. Respir Res. 2019;20:119.

181. King TE Jr, Bradford WZ, Castro-Bernardini S, Fagan EA, Glaspole I, Glassberg MK, Gorina E, Hopkins PM, Kardatzke D, Lancaster L. A phase 3 trial of pirfenidone in patients with idiopathic pulmonary fibrosis. N Engl J Med. 2014;370:2083-92.

182. Li M, Ping G, Plathow C, Trinh T, Lipson KE, Hauser K, Krempien R, Debus J, Abdollahi A, Huber PE. Small molecule receptor tyrosine kinase inhibitor of platelet-derived growth factor signaling (SU9518) modifies radiation response in fibroblasts and endothelial cells. BMC Cancer. 2006;6:79.

183. Abdollahi A, Li M, Ping G, Plathow C, Domhan S, Kiessling F, Lee LB, McMahon G, Gröne H-J, Lipson KE. Inhibition of platelet-derived growth factor signaling attenuates pulmonary fibrosis. J Exp Med. 2005;201:925-35.

184. Daniels CE, Lasky JA, Limper AH, Mieras K, Gabor E, Schroeder DR. Imatinib treatment for idiopathic pulmonary fibrosis: randomized placebo-controlled trial results. Am J Respir Crit Care Med. 2010;181:604-10.

185. Richeldi L, Du Bois RM, Raghu G, Azuma A, Brown KK, Costabel U, Cottin V, Flaherty KR, Hansell DM, Inoue Y. Efficacy and safety of nintedanib in idiopathic pulmonary fibrosis. N Engl J Med. 2014;370:2071-82.

186. Kolb M, Raghu G, Wells AU, Behr J, Richeldi L, Schinzel B, Quaresma M, Stowasser S, Martinez FJ. Nintedanib plus sildenafil in patients with idiopathic pulmonary fibrosis. N Engl J Med. 2018;379:1722-31.

187. Bickelhaupt S, Erbel C, Timke C, Wirkner U, Dadrich M, Flechsig P, Tietz A, Pföhler J, Gross W. Peschke P. Effects of CTGF blockade on attenuation and reversal of radiation-induced pulmonary fibrosis. JNCI J Natl Cancer Inst. 2017:109:djw339.

188. Lipson K, Moustafa M, Akbarpour M, Fouse S, Kriegsmann M, Zhou C, Liu K, Lasitschka F, Weichert W, Seeley T. Therapeutic pamrevlumab (FG-3019) is more effective than pirfenidone or nintedanib in a mouse radiation-induced lung fibrosis model; 2017.

189. Richeldi L, Pérez ERF, Costabel U, Albera C, Lederer DJ, Flaherty KR, Ettinger N, Perez R, Scholand MB, Goldin J. Pamrevlumab, an anti-connective tissue growth factor therapy, for idiopathic pulmonary fibrosis (PRAISE): a phase 2, randomised, double-blind, placebo-controlled trial. Lancet Respir Med. 2020; 8:25-33.

190. de Leve S, Wirsdörfer F, Jendrossek V. The CD73/ado system-a new player in RT induced adverse late effects. Cancers. 2019;11:1578.

191. Wirsdörfer F, de Leve S, Cappuccini F, Eldh T, Meyer AV, Gau E, Thompson $L F$, Chen $N-Y$, Karmouty-Quintana H, Fischer U. Extracellular adenosine production by ecto-5'-nucleotidase (CD73) enhances radiation-induced lung fibrosis. Cancer Res. 2016;76:3045-56.

192. Liu X, Cotrim A, Teos L, Zheng C, Swaim W, Mitchell J, Mori Y, Ambudkar I. Loss of TRPM2 function protects against irradiation-induced salivary gland dysfunction. Nat Commun. 2013:4:1-10.

193. Perraud A-L, Rao DM, Kosmacek EA, Dagunts A, Oberley-Deegan RE, Gally F. The ion channel, TRPM2, contributes to the pathogenesis of radiodermatitis. Radiat Environ Biophys. 2019:58:89-98.

194. Dietrich A. Modulators of transient receptor potential (TRP) channels as therapeutic options in lung disease. Pharmaceuticals. 2019:12:23.
195. Nicolay NH, Perez RL, Debus J, Huber PE. Mesenchymal stem cells-a new hope for radiotherapy-induced tissue damage? Cancer Lett. 2015:366:13340

196. Zanoni M, Cortesi M, Zamagni A, Tesei A. The role of mesenchymal stem cells in radiation-induced lung fibrosis. Int J Mol Sci. 2019;20:3876.

197. Klein D, Steens J, Wiesemann A, Schulz F, Kaschani F, Röck K, Yamaguchi M, Wirsdörfer F, Kaiser M, Fischer JW. Mesenchymal stem cell therapy protects lungs from radiation-induced endothelial cell loss by restoring superoxide dismutase 1 expression. Antioxid Redox Signal. 2017;26:563-82.

198. Dong L-H, Jiang Y-Y, Liu Y-J, Cui S, Xia C-C, Qu C, Jiang X, Qu Y-Q, Chang P$Y$, Liu F. The anti-fibrotic effects of mesenchymal stem cells on irradiated lungs via stimulating endogenous secretion of HGF and PGE2. Sci Rep. 2015;5:8713

199. Averyanov A, Koroleva I, Konoplyannikov M, Revkova V, Lesnyak V, Kalsin V, Danilevskaya O, Nikitin A, Sotnikova A, Kotova S. First-in-human highcumulative-dose stem cell therapy in idiopathic pulmonary fibrosis with rapid lung function decline. Stem Cells Transl Med. 2020;9:6-16.

200. Chambers DC, Enever D, Ilic N, Sparks L, Whitelaw K, Ayres J, Yerkovich ST, Khalil D, Atkinson KM, Hopkins PM. A phase 1b study of placenta-derived mesenchymal stromal cells in patients with idiopathic pulmonary fibrosis. Respirology. 2014;19:1013-8.

201. Hanania AN, Mainwaring W, Ghebre YT, Hanania NA, Ludwig M. Radiationinduced lung injury: assessment and management. Chest. 2019;156(1):15062.

202. Sara A-G, Hamdan A-J, Hanaa B, Nawaz KA. Bronchiolitis obliterans organizing pneumonia: pathogenesis, clinical features, imaging and therapy review. Ann Thorac Med. 2008;3:67

\section{Publisher's Note}

Springer Nature remains neutral with regard to jurisdictional claims in published maps and institutional affiliations.

Ready to submit your research? Choose BMC and benefit from:

- fast, convenient online submission

- thorough peer review by experienced researchers in your field

- rapid publication on acceptance

- support for research data, including large and complex data types

- gold Open Access which fosters wider collaboration and increased citations

- maximum visibility for your research: over $100 \mathrm{M}$ website views per year

At $\mathrm{BMC}$, research is always in progress.

Learn more biomedcentral.com/submissions 